Article

\title{
Snapshot Study of Whole Genome Sequences of Escherichia coli from Healthy Companion Animals, Livestock, Wildlife, Humans and Food in Italy
}

\author{
Elisa Massella ${ }^{1}$, Cameron J. Reid ${ }^{2}$, Max L. Cummins ${ }^{2}$, Kay Anantanawat ${ }^{2}$, Tiziana Zingali ${ }^{2}$, \\ Andrea Serraino ${ }^{1} \mathbb{D}$, Silvia Piva ${ }^{1}$, Federica Giacometti ${ }^{1}$ and Steven P. Djordjevic ${ }^{2, *(D)}$ \\ 1 Department of Veterinary Medical Sciences, University of Bologna, 40126 Bologna, Italy; \\ elisa.massella@libero.it (E.M.); andrea.serraino@unibo.it (A.S.); silvia.piva@unibo.it (S.P.); \\ federica.giacometti3@unibo.it (F.G.) \\ 2 The ithree Institute, University of Technology Sydney, City Campus, Ultimo, NSW 2007, Australia; \\ cameron.reid@uts.edu.au (C.J.R.); max.cummins@uts.edu.au (M.L.C.); kay.anantanawat@uts.edu.au (K.A.); \\ tizianazingali@gmail.com (T.Z.) \\ * Correspondence: steven.djordjevic@uts.edu.au
}

Received: 15 September 2020; Accepted: 5 November 2020; Published: 6 November 2020

\begin{abstract}
Animals, humans and food are all interconnected sources of antimicrobial resistance (AMR), allowing extensive and rapid exchange of AMR bacteria and genes. Whole genome sequencing (WGS) was used to characterize 279 Escherichia coli isolates obtained from animals (livestock, companion animals, wildlife), food and humans in Italy. E. coli predominantly belonged to commensal phylogroups B1 (46.6\%) and A (29\%) using the original Clermont criteria. One hundred and thirty-six sequence types (STs) were observed, including different pandemic (ST69, ST95, ST131) and emerging (ST10, ST23, ST58, ST117, ST405, ST648) extraintestinal pathogenic Escherichia coli (ExPEC) lineages. Eight antimicrobial resistance genes (ARGs) and five chromosomal mutations conferring resistance to highest priority critically important antimicrobials (HP-CIAs) were identified

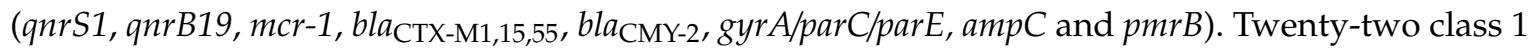
integron arrangements in 34 strains were characterized and 11 ARGs were designated as intI1 related gene cassettes (aadA1, aadA2, aadA5, aad23, ant2_Ia,dfrA1,dfrA7,dfrA14,dfrA12, dfrA17, cmlA1). Notably, most intI1 positive strains belonged to rabbit (38\%) and poultry $(24 \%)$ sources. Three rabbit samples carried the $m c r-1$ colistin resistance gene in association with IS6 family insertion elements. Poultry meat harbored some of the most prominent ExPEC STs, including ST131, ST69, ST10, ST23, and ST117. Wildlife showed a high average number of virulence-associated genes (VAGs) $($ mean $=10)$, mostly associated with an ExPEC pathotype and some predominant ExPEC lineages (ST23, ST117, ST648) were identified.
\end{abstract}

Keywords: commensal Escherichia coli; antimicrobial resistance; whole genome sequencing; genomic epidemiology

\section{Introduction}

Antimicrobial resistance has been recognized as one of the world's most pressing public health problems, with implications for human and veterinary medicine, wildlife and environmental ecosystems. In recent decades we have witnessed a dramatic spread and diffusion of multidrug resistant (MDR) pathogens. In the context of human medicine, the decrease in bacterial susceptibility to critically important antimicrobials (CIAs) and the quick diffusion of extended-spectrum beta lactamase (ESBL) producers are a major concern [1]. 
The consequences of MDR are particularly severe and characterized by an increase in infection severity, treatment failure, hospitalizations and mortality, with growing costs for health care. It has been estimated that AMR causes 700,000 deaths every year globally, with 25,000 victims and over $€ 1.5$ billion in healthcare costs in the European Union (EU) [2].

Horizontal gene transfer (HGT) plays a primary role in the exchange of genetic material amongst bacteria and allows them to evolve and adapt rapidly to novel selective pressures. HGT of ARGs is mediated by mobile genetic elements (MGEs) and facilitated by the interconnection between bacteria, their hosts and the environment [3]. Animals (livestock, companion animals, wildlife), the community, hospital and industrial settings (including food-production) have been investigated as possible sources of AMR [4-6]. The interaction between these environments is complex and understanding vectors of AMR transfer is a central tenet in mitigation efforts to limit its impact. Municipal, agricultural and industrial wastewater, aquaculture, animal manure and sewage sludge have been recognized as major pathways of AMR transmission between different ecosystems [7,8]. Data describing spatial and temporal trends of AMR carriage are essential for epidemiological evaluation and preventive measure implementation. In this context, the European Union has defined AMR as a special health issue to be monitored by epidemiological surveillance systems [9].

Escherichia coli (E. coli) are commensal inhabitants of the gastrointestinal tract of mammals and most vertebrate species, can proliferate in diverse aquatic environments and are often resistant to multiple antibiotics. E. coli: (i) exists in feces as a commensal or as a pathogen and is frequently exposed to antimicrobial selection pressures; (ii) can cause intestinal and extraintestinal disease in humans and animals; and (iii) lives freely in water and colonizes wild animal vectors such as birds and insects $[10,11]$. Because of these features, combined with the capacity to acquire genetic material via HGT, E. coli is a bacterium of choice for studying AMR from a One Health perspective [12].

From a global perspective, extensive genomic evaluation of ARGs, VAGs and their association with MGEs in nonclinical E. coli is generally lacking. Most studies have typically relied on phenotypic AMR and molecular analyses of pathogens [13-16]. Prior to WGS, genotypic evaluation was mainly performed by polymerase chain reaction (PCR) without considering the often mosaic and complex mobile antimicrobial genetic structures involved. This is particularly evident in Italian studies [17-20]. However, in recent years WGS has been increasingly used to examine drug-resistant commensal and pathogenic E. coli from humans [21-23], food animals [24-26], fresh produce [26,27], companion animals [28], wildlife [29], wastewater [30] and in pristine aquatic environments [31]. Despite these efforts, an exhaustive knowledge of AMR mechanisms, sources and epidemiology is still lacking.

Italy in particular, currently lacks this data, rarely performing WGS to characterise AMR in E. coli indicator from human and animal sources or from food and wildlife.

Here, we present WGS of 279 commensal E. coli, isolated from different sources (including livestock, companion animals, wildlife, food and humans) in Italy. We provide data related to their phylogenetic diversity, carriage of ARGs, VAGs, biocide resistance genes and their association with MGEs.

\section{Results}

The original collection consisted of 288 E. coli strains. Nine of these (EM1_Be20, EM1_Ca14, EM1_Fs21, EM1_Rb15, EM1_Rb25, EM1_Ve16,WM1_Wb2, EM1_Wb24, EM1_Wb25) were excluded due to PCR misidentification or inadequate DNA quality. Therefore, the final study collection consisted of 279 E. coli ( 25 poultry; 25 swine; 25 dairy; 25 human; 25 mollusc; 25 wild animal; 24 beef; 24 vegetable; 24 fish; 23 rabbit; 22 wild boar; 12 companion animal).

\subsection{In Silico Typing and Phylogeny}

A total of 136 sequence types were identified, with ST10 (16; 5.7\%), ST155, ST847 (both 9; 3.2\%), ST69 $(8 ; 2.9 \%)$, ST20 (7; 2.5\%), ST23, ST117, ST216 (all 6; 2.2\%) being the most common. Ninety-five sequence types were represented by a single isolate. Most sources displayed a diversity of STs, 
though some exhibited clonality including beef, swine and poultry with eight ST847, six ST10 and five ST117, respectively.

One hundred and fifty-eight different serotypes were predicted for the 279 strains analyzed. Forty-four strains were $\mathrm{O}$ nontypable with 20 different $\mathrm{H}$ types, meanwhile for one $\mathrm{O} 107$ isolate, the $\mathrm{H}$ type was not determined. Serotype variability was pronounced among sources, except for human sources with six O1:H7 strains (4, ST59; 2, ST95).

The most common phylogroup identified among the collection was B1 (130; 46.6\%), followed by A $(81,29 \%) \mathrm{D}(47 ; 16.8 \%)$ and B2 $(21 ; 7.5 \%)$. Most beef, companion animal, mollusc, rabbit, vegetable and wild animal strains $(\geq 50 \%$ ) belonged to phylogroup B1. Meanwhile phylogroup A was the most represented $(\geq 40 \%)$ in dairy, fishery, poultry and swine sources. Phylogroup D was prevalent in human $(12 / 25 ; 48 \%)$ and wild boar $(11 / 22 ; 50 \%)$ isolates. Interestingly, wild boar and wild animal sources contained the highest number of B2 strains (6 and 3, respectively), which are usually associated with pathogenicity.

Phylosift analysis produced a maximum-likelihood tree (Figure 1) with the first major split separating phylogroups B2 and D from A and B1. Tree topology was highly congruent with Achtman MLST and generally congruent with phylogroup distribution. Clade 1 was composed of two subclades, one mostly comprising phylogroup B2 and one primarily phylogroup D. ST69 was the prevalent sequence type of clade 1 with eight strains. Clade 2 was split into four subclades, the first mostly containing phylogroup $\mathrm{D}$, the second and third were primarily phylogroup $\mathrm{A}$ and the fourth was dominated by phylogroup B1. The most common lineage of clade 2 was ST10 (16) all belonging to subclade 2. Strains of the same source clustered on distinct branches in some cases. However, sources were generally distributed across multiple clades.
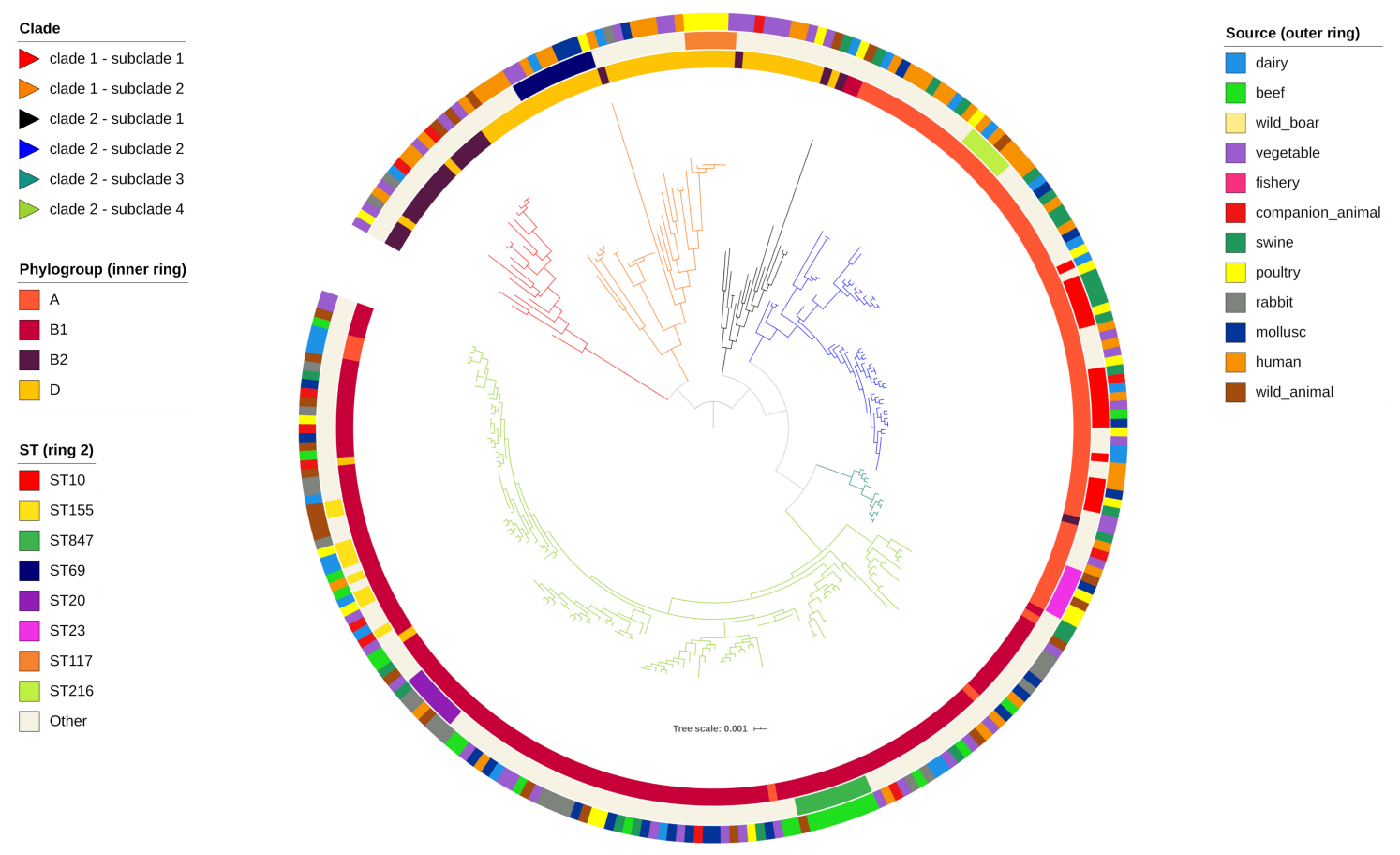

Figure 1. A mid-point rooted, maximum-likelihood phylogenetic tree of 279 commensal E. coli included in the study. Branches are colored by clade and subclade according to the legend. Phylogroups (inner ring), sequence types (middle ring) and sources (outer ring) are annotated according to the legend.

\subsection{Antimicrobial Resistance Genes}

One hundred and seventy-nine strains (64.2\%) did not carry ARGs. The remaining 100 (35.8\%) isolates carried between one and 16 ARGs, with 77 (71.3\%) strains containing at least three. Among the 
latter, $43 / 77$ (55.8\%) strains belonged to phylogroup B1, 20/77 (26\%) to phylogroup A, 12/77 (15.6\%) to phylogroup D and 2/77 (26\%) to phylogroup B2. Interestingly, most strains carrying $\geq 10$ ARGs belonged to phylogroups B1 (6/11) and A (3/11). Forty-six different ARGs were identified in our collection (Figure 2), with tetracycline resistance gene tet $A(57 / 279 ; 20.4 \%)$, sulfonamide resistance gene sul2 $(45 / 279 ; 16.1 \%)$, penicillin resistance gene $b_{1} a_{T E M-1 b}(43 / 279 ; 15.4 \%)$ and streptomycin resistance genes $s t r A / B(42 / 279 ; 15.1 \%)$ being the most common. Colistin resistance gene $m c r-1$ was discovered in six $(2.2 \%)$ strains, namely three rabbit, two swine and one dairy strain. Genes encoding extended spectrum beta-lactamases (bla $\left.a_{C T X-M-1}, b l a_{C T X-M-15}, b l a_{C T X-M-55}\right)$ were identified in 4 (1.4\%) isolates, namely two dairy, one wild animal and one human. All ESBL strains carried a high number of ARGs (mean =9) and VAGs (mean = 16). AmpC beta lactamase gene bla ${ }_{C M Y-2}$ was identified in one human isolate. Fluoroquinolone resistance genes ( $q n r S 1$ and qnrB19) were discovered in two dairy, one human and one rabbit strain. The mean number of ARGs present in each source was: rabbit eight; poultry four; dairy three; swine and human two each; wild animal, beef, companion animal, mollusc and fishery, one each. The sources carrying the lowest number of ARGs were vegetable and wild boar, with only two and one resistant strains, respectively (Figure 3). Mutations in gyrA, parC and parE genes, conferring presumptive fluoroquinolone resistance, were identified in 61 strains, mostly of rabbit (17/54), poultry (13/54) and human (9/54) origin. Point mutation in the AmpC promoter, associated with hypothetical AmpC-type cephalosporinase expression, was identified in two beef strains. A single swine isolate contained SNPs in $p m r B$, conferring presumptive resistance to colistin. Heavy metal resistance genes mer $A$ and ter $A$, conferring resistance to mercury and tellurium were identified in 34 and 19 isolates, respectively.

\subsection{Virulence-Associated Genes}

The whole collection was screened for VAGs associated with ExPEC and intestinal pathogenic E. coli (IPEC) pathotypes. One hundred and eleven different VAGs were identified (Figure 4). All strains carried between one and 37 VAGs. A high number $(\geq 10)$ of virulence determinants were identified in $102(36.6 \%)$ isolates, most of them belonging to phylogroup B1 $(41,40.2 \%)$, followed by D $(27 ; 26.5 \%)$, A $(21,20.6 \%)$ and B2 (13; 12.7\%). Most VAGs were typical of ExPEC pathotype, including different genes encoding for adhesins (fimH, pap, iha, bmaE, sfaS), invasins (ibeA), iron acquisition systems (iucD, iutA, fyuA, irp2, iroN, ireA, tsh, sitA), toxins (hlyE, cnf1, cdtB, usp, sat, picU, vat) and protectins (kpsMT-II, traT, ompT, iss, cvaC). Both ExPEC and IPEC VAGs were identified in four ST20 and four ST40 strains from rabbits. The mean number of VAGs for each source was: poultry and human, 15 each; rabbit, 14; companion animal and wild animal, 11 each; swine, 10; wild boar, dairy, mollusc, 8 each; beef and vegetable, 6 each; fishery, 5 (Figure 5). Three strains (1.1\%) carried $\geq 30$ VAGs, including two from poultry (1, ST117; 1, ST131) and one ST648 from a wild animal (stork).

\subsection{Class 1 Integron Structures}

Short read screening identified the intI1 class 1 integrase gene in 50/279 (17.9\%) strains, mostly present in phylogroup B1 (31/50; 62\%), followed by A and D (9/50; $18 \%$ each) and B2 (1/50; $2 \%)$.

Following de novo assembly, we identified 44 strains with scaffolds carrying a complete intI1 gene. Thiry-four of 44 strains carried cassette array genes and were annotated in order to characterize the different integron structures present in the collection. Twenty-three arrangements were characterized and designated letters (A-W). Derivatives of (A-W) were named with the letter of the principal structure followed by a number (Figure 6). Eleven ARGs were identified as intI1 related gene cassettes, namely those conferring resistance to aminoglycosides; aadA1, aadA2, aadA5, aad23, ant2_Ia, trimethoprim; $d f r A 1, d f r A 7, d f r A 12, d f r A 14, d f r A 17$, and chloramphenicol; cmlA1. The most common integron cassette array was aadA1-dfrA1, present in 14/35 (40\%) strains. Both sul1 and sul3 were identified in the 3'-CS of characterized integrons. Two isolates (one human and one poultry strains) harbored both intI1 and intI2 integrase genes. 


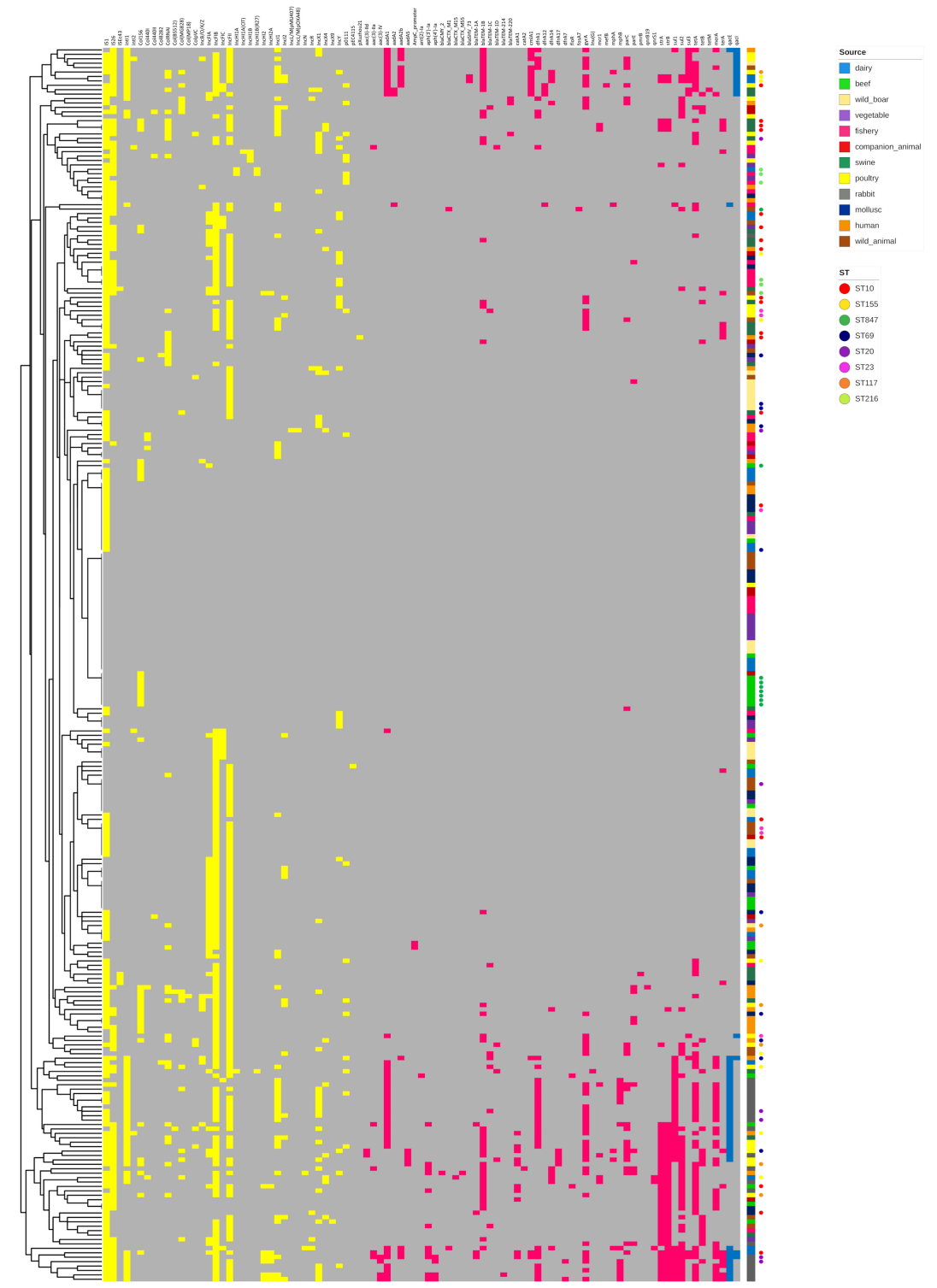

Figure 2. Heat map depicting carriage of mobile genetic elements (MGEs, yellow), antimicrobial resistance genes (ARGs red) and plasmid mediated quarternary ammonium compound (QAC) resistance genes (blue) in the strain collection. Grey indicates absence. The dendrogram on the left represents clustering of E. coli isolates according to genetic profile similarities.

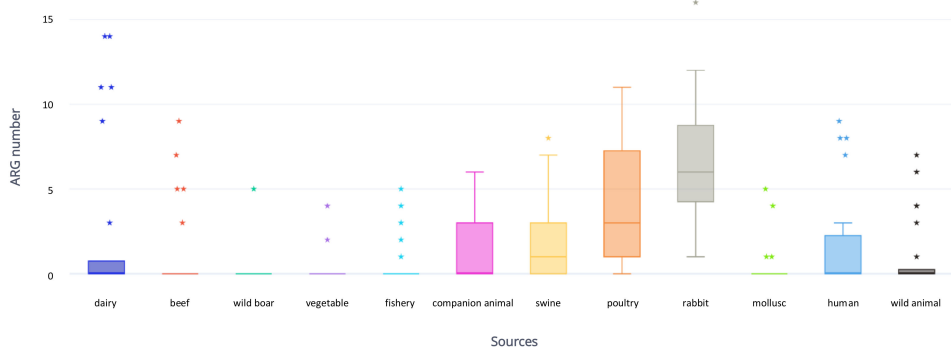

Figure 3. Box plot representing ARG number and distribution in the different sources considered in the study (poultry, swine, human, mollusc, wild animal, dairy, $\mathrm{n}=25$; beef, vegetable and fishery, $\mathrm{n}=24$; rabbit, $\mathrm{n}=23$; wild boar, $\mathrm{n}=22$; companion animal, $\mathrm{n}=12$ ). $\star$ : outlier. 


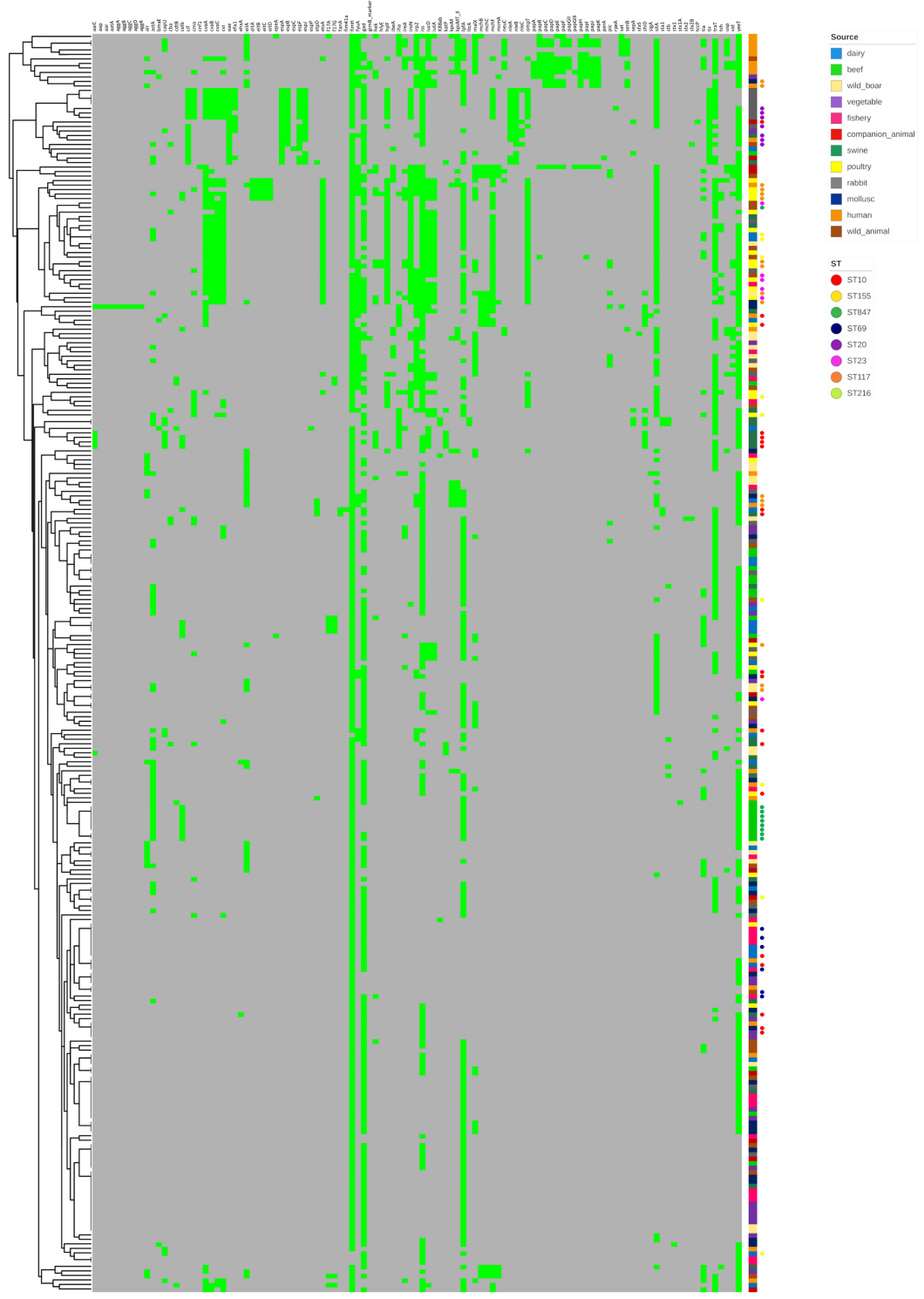

Figure 4. Heat map depicting VAG carriage (light green) in the strain collection. Grey indicates absence. The dendrogram on the left represents clustering of E. coli isolates according to genetic profile similarities.

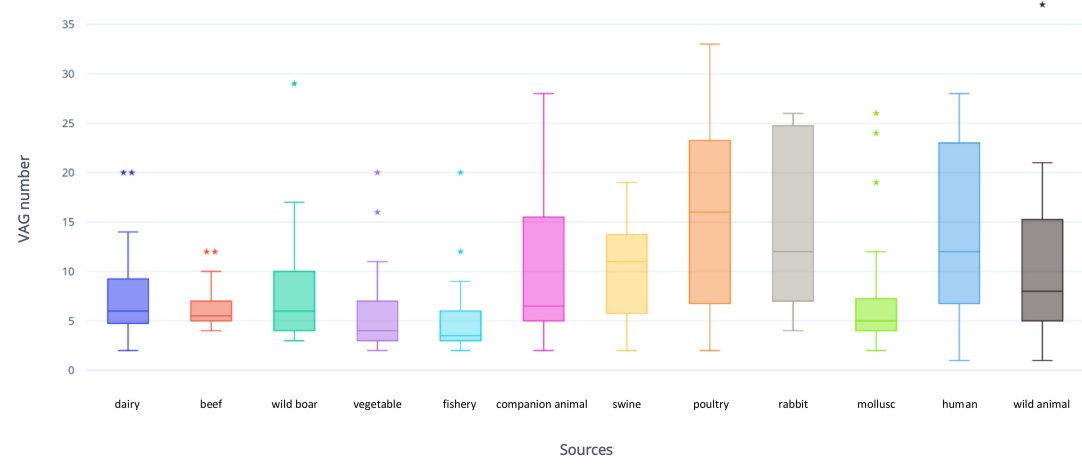

Figure 5. Box plot representing VAG number and distribution in the different sources considered in the study (poultry, swine, human, mollusc, wild animal, dairy, $\mathrm{n}=25$; beef, vegetable and fishery, $\mathrm{n}=24$; rabbit, $\mathrm{n}=23$; wild boar, $\mathrm{n}=22$; companion animal, $\mathrm{n}=12$ ). $\star$ : outlier. 


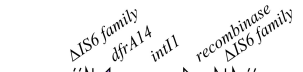

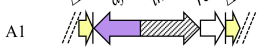

Rb21, ST1431; Rb24, ST1727

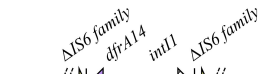

A2 // W viduty

\section{Hu21, ST457}

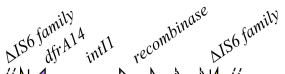

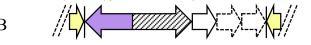

Da13, ST155

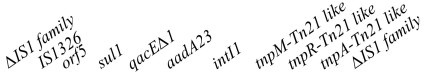

C

Sw11, ST871

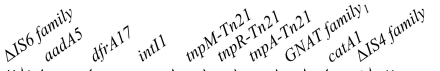

$\mathrm{D} / / \mathrm{C} / \mathrm{C}$

PI22, ST117

(5)

E /

$\mathrm{Rb} 11, \mathrm{ST} 20$

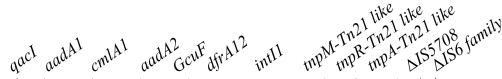

F1

SW2, ST641

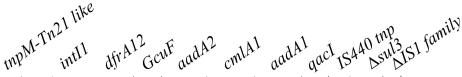

F2

PI23, ST10

(1)

PI4, ST131

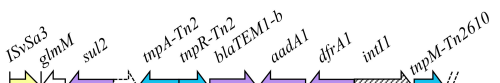

G2

PI20, ST1286

s.5.

H

$\mathrm{Rb} 4, \mathrm{ST} 20$

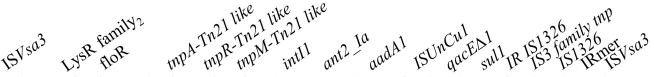

I

Be24, ST58

20

, $/ 2$ X

Be1, ST297 (x)

к.

$\mathrm{Rb} 12, \mathrm{ST} 129$ (nit)

K2

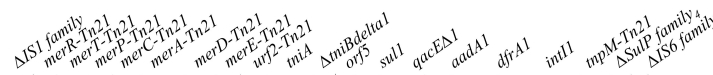

$\mathrm{Rb1}, \mathrm{ST} 40 ; \mathrm{Rb} 6, \mathrm{ST} 40$ Rb16, ST351; Rb17, ST501

$\mathrm{L} / / \mathrm{A}$

Rb10, ST533

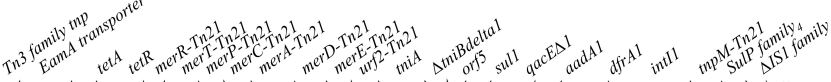

M1

$\mathrm{Rb} 3, \mathrm{ST} 40$ and

M2

Figure 6. Cont. 


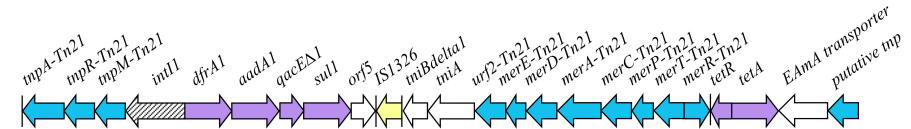

$\mathrm{Rb} 19, \mathrm{ST} 111$

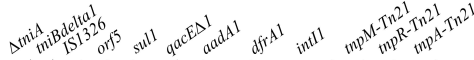

N2 /

$\mathrm{Rb} 7, \mathrm{ST} 20$

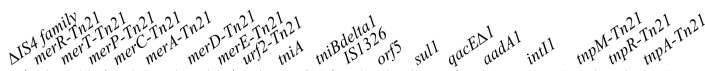

o

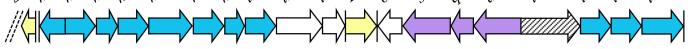

Da5, Novel

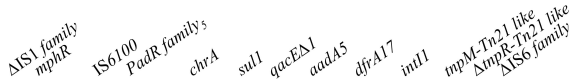

P

$\mathrm{Rb} 20, \mathrm{ST} 539$

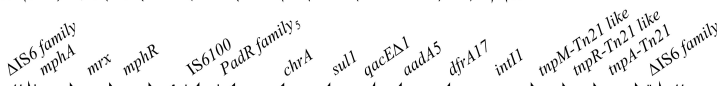

Q $\quad / \quad \Rightarrow \Rightarrow \Rightarrow \Rightarrow$

$\mathrm{PI} 6$, ST744

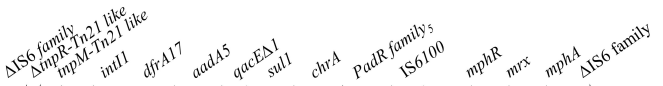

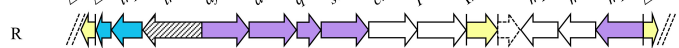

PI18, ST69

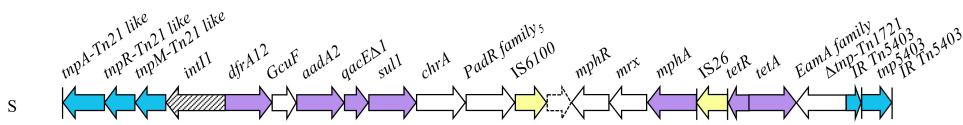

Fs1, ST540

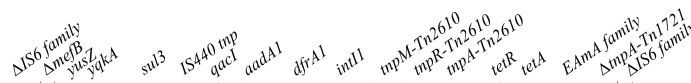

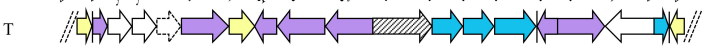

Wb23, ST162

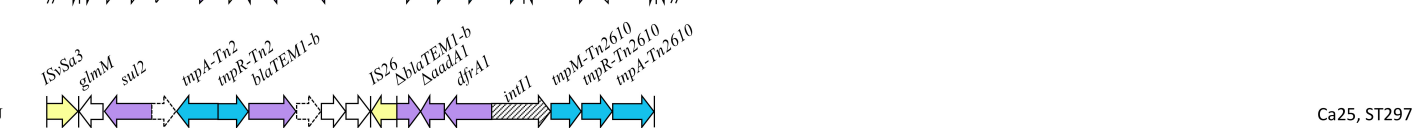

$\mathrm{u} \quad \mathrm{X}>\mathrm{C}$

Ca25, ST297

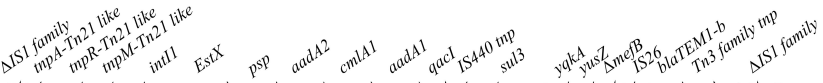

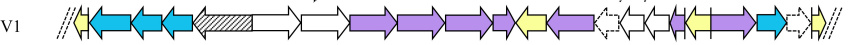

PI10, ST162

V2

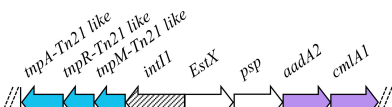

PI7, ST57

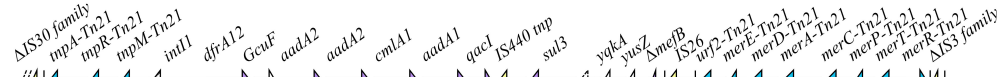

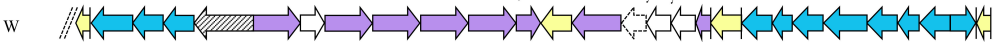

Figure 6. Schematic diagram (not to scale) of integron structures identified in 34 commensal E. coli. Arrows represent ORFs. Arrows with broken lines indicate hypothetical proteins. Vertical bars represent inverted repeats. Dashed double diagonal lines represent sequence scaffold breaks. Elements displayed are color coded (ARGs = purple; IS elements = yellow; transposon elements = light blue) . 1: N-acetyltransferase, GNAT family; 2: transcriptional regulator, LysR family; 3: homologue of IS801 transposase like protein of Pseudomonas pseudoalcaligenes; 4: SulP family inorganic anion transporter; 5: PadR family transcriptional regulator; orfA: homologue of penicillin-binding protein 4 of Streptomyces lactamdurans; orfB: homologue of AcrR potential operon repressor; orfC: homologue of RdmC protein of Streptomyces purpurascens.

\subsection{Antibiotic Resistance Gene Carriage in Strains Carrying intI1 Compared with Those That Do Not Carry intI1}

Short read sequencing indicated that 50/279 (17.9\%) strains carried intI1 (intI1 ${ }^{+}$), most of them isolated from food-producing animals $(19 / 50 ; 38 \%)$ and related food $(24 / 50 ; 48 \%)$. In particular, rabbit $(19 / 50 ; 38 \%)$ and poultry $(12 / 50 ; 24 \%)$ sources were the most represented, followed by four human (8\%), two wild animal (4\%), one companion animal (2\%) and one fishery (2\%). As expected, a higher number of ARGs was harbored by intI1 ${ }^{+}$strains compared to strains that were intI1- 
with a mean of seven to one respectively (Figure 7). ARGs which are usually not a part of the typical class 1 integron structure, including tet $A$ (int $11^{+}, 42 / 50,84 \%$; intI1 ${ }^{-}$34/229, 14.8\%), bla TEM (intI1 $^{+}$33/50, 66\%; intI1- 30/229, 13.1\%) and strA/B (intI1 ${ }^{+}, 22 / 50,44 \%$; int I1- 22/229, 9.6\%), were present in both groups. As expected, aminoglycoside (aadA) and trimethoprim ( $(f r)$ resistant determinants, widely observed as gene cassettes, were widespread among intI $1^{+}$strains (43/50, 86\% and $46 / 50,92 \%$ respectively) and rare in intI1 ${ }^{-}$isolates $(3 / 229,1.3 \%$ and $5 / 229,2.2 \%$, respectively). ESBL, polymyxin, and quinolone resistance genes were rarely identified among intI1 ${ }^{+}(2 / 50,4 \% ; 4 / 50,8 \% ; 2 / 50,4 \%$ respectively) and intI1 $^{-}\left(2 / 229,0.9 \% ; 2 / 229,0.9 \% ; 2 / 229,0.9 \%\right.$ respectively) isolates. bla ${ }_{C M Y-2}$ gene was harbored by a single intI1 ${ }^{+}$isolate. VAGs appeared to be more common in $i n t I 1^{+}$strains when compared to the int11- group, with means of 14 and 9 respectively (Figure 8). The IncF plasmid replicon was the most frequent in both intI1 ${ }^{+}(47 / 50,94 \%)$ and intI1- $(135 / 229,59 \%)$ strains. Notably, pandemic (ST69, ST95, ST131) and emerging (ST10, ST23 ST58, ST117, ST405, ST648) ExPEC lineages were present in both groups (intI1 ${ }^{+} 8 / 50,16 \%$; intI1, 37/229, 16.2\%).

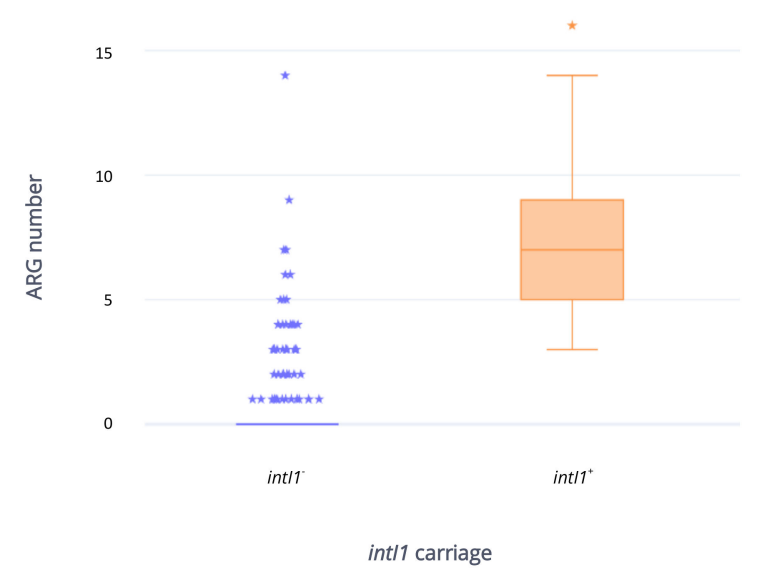

Figure 7. Box plot representing ARGs number and distribution in intI1 ${ }^{+}(\mathrm{n}=50)$ and intI1- $(\mathrm{n}=229)$ strains considered in the study. $\star$ : outlier.

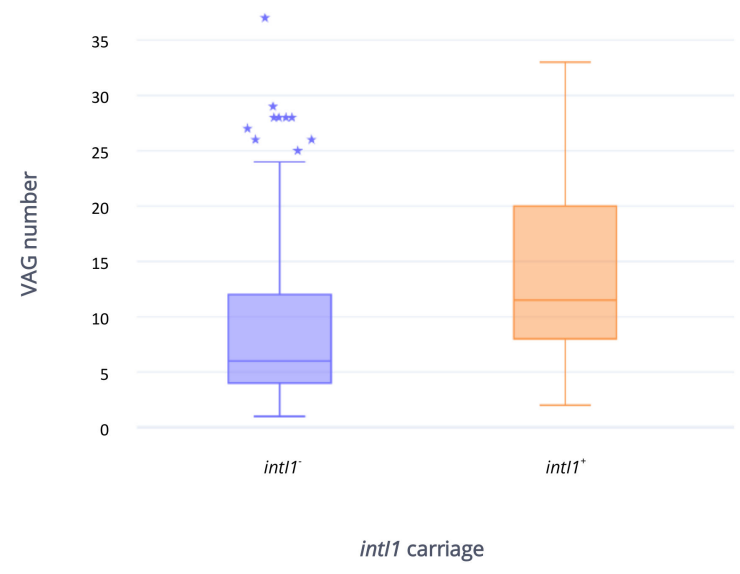

Figure 8. Box plot representing VAGs number and distribution in $\operatorname{intI1}^{+}(\mathrm{n}=50)$ and intI1- $(\mathrm{n}=229)$ strains considered in the study. $\star$ : outlier.

\subsection{Plasmid Incompatibility Groups}

Thirty-three different plasmid replicons (Figure 2) were identified in the collection. IncF was the most common $(182 / 279 ; 65.2 \%)$, whilst IncI $(57 / 279 ; 20.4 \%)$ and IncX $(45 / 279 ; 16.1 \%)$ were also frequently observed. These replicons were present across multiple sequence types. 


\subsection{Biocide Resistance Genes}

Our collection was screened for different efflux pump genes and related regulators linked with the extrusion of a wide variety of molecules, including biocides and antimicrobials. Most genetic determinants, known to be chromosomally encoded, were widespread. Genes involved in quaternary ammonium compound resistance (emrE, $m d f A$ ), oxidative stress tolerance and protection/peroxygens resistance $(i b p A, i b p B, \operatorname{sod} A, \operatorname{sod} B, y d e I, y m g B)$ and phenolic compound resistance $(a c r A B, f a b I)$ were frequently identified. Integron-associated qacE and qacI genes were mostly identified in rabbit (17) and poultry (10) sources, alone or in combination (Figure 2).

Complete VAG, ARG, MGE and efflux pump/biocide resistant gene carriage data are available in Supplementary Materials (Tables S1, S3 and S4).

\section{Discussion}

Using WGS we characterized 279 E. coli recovered from diverse animal and food sources in Italy to garner insight into the diversity of $E$. coli sequence types and the antimicrobial resistance and virulence genes they carry. We observed 136 E. coli STs, including pandemic (ST69, ST95, ST131) and emerging (ST10, ST23, ST58, ST117, ST405, ST648) EXPEC lineages. Most of the strains did not carry class 1 integrons but intI1 ${ }^{+}$isolates carried more ARGs compared to those that were intI1- ${ }^{-}$. Class 1 integron structure analysis among 50/279 (17.9\%) intI1 ${ }^{+}$strains identified 22 class 1 integron variants among 34 structures. Limitations of short read sequence data precluded analysis of the remaining 16 class 1

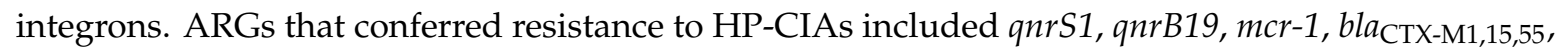
and $b l a_{\mathrm{CMY}-2}$. Chromosomal mutations in $g y r A / p a r C / p a r E$ were notable in poultry and rabbit sources.

\subsection{Antimicrobial Resistance}

The most common ARGs in all sources were tet (mostly tetA, 57/279), sul (mostly sul2, 45/279) and bla $a_{\mathrm{TEM}}$ (mostly bla $a_{\mathrm{TEM}-1 \mathrm{~b}}, 43 / 279$ ). These genes are generally reflective of common phenotypic resistance profiles of commensal E. coli of animal, food and human origin previously reported in Europe [12,18,32-36]. The tet-sul-bla $a_{\mathrm{TEM}}$ genetic profile in livestock (cattle, swine, poultry, rabbit) reflects resistance to the most commonly used antimicrobials in Italian livestock production [37]. This profile was also observed in environments not commonly associated with direct antimicrobial selective pressure, like aquaculture (molluscs and fish), vegetables and wildlife. Resistance to tetracycline, sulfonamides and beta-lactams has been reported in aquaculture $[35,38]$ and vegetables $[36,39,40]$ in Europe. However, Italian data about AMR are lacking, probably due to the rare or absent antimicrobial use in these sectors [41]. Hence, a proper comparison between our findings and previous phenotypic reports in these sources is difficult to perform. A similar phenotypic AMR profile has been previously reported in wildlife [42,43], considered an AMR bioindicator [42,44,45] primarily because related AMR is strictly influenced by livestock and human density/activity [46,47].

The consistency of AMR profile identified in aquaculture, vegetables and wildlife with those observed in livestock, humans and companion animals supports AMR diffusion from settings with high antimicrobial use. Fecal contamination is considered the major path for AMR bacteria, genes and antimicrobial residues diffusion $[7,8,32,48,49]$. Sewage and manure contaminate groundwater and aquatic systems. Therefore, irrigation water and manure-based fertilizers may act as carriers of AMR bacteria and genes, polluting agricultural production [36,50]. Similarly, sewage and runoff from land could be responsible for AMR observed in aquaculture systems [51-53].

Streptomycin resistance genes $\operatorname{str} A / B$ were frequently observed $(42 / 279 ; 15 \%)$. Our findings are generally consistent with previous studies [18,32,35,36,54,55], barring the low levels of phenotypic aminoglycoside co-resistance typically reported in swine, poultry and beef $[12,33,56,57]$. Currently, streptomycin has limited therapeutic usage in both humans and animals in Europe $[37,58]$. However, str $A / B$ are common streptomycin determinants among Enterobacteriaceae isolated from humans and animals [25,59]. str $A / B$ are usually genetically linked and have been frequently associated 
with Tn5393 [60] and Tn6029/Tn6026 [61] on different multi-resistance plasmids (including IncH1, IncH2, IncHII, IncZ, IncN, IncQ, IncU) [62], circulating in bacterial populations. Moreover, these genes are often clustered on different plasmids with the sul2 gene [63,64], encoding resistance to some of the most frequently sold antimicrobials for livestock. The abundance of $\operatorname{str} A / B$ might, therefore, be explained by co-selection.

Cephalosporins (third, fourth and fifth generation), polymyxins and quinolones are considered HP-CIAs, the last-line of treatment for serious human infections. ESBL and polymixin ARGs, and pmr chromosomal mutations were detected in low frequency among the collection and were mostly identified in food-producing animals and related food. Our findings are in accordance with low cephalosporin and colistin phenotypic resistance identified in $E$. coli from livestock and related meat in Europe $[12,18,33,35,56,57]$. Nonetheless, $m c r-1$ and $m c r-2$ colistin resistance genes have been reported in European E. coli from poultry in Romania [65] and poultry and swine in Spain [66].

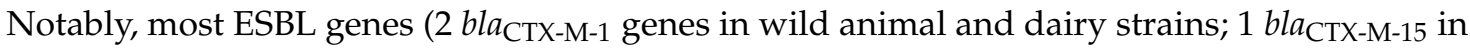
a dairy strain; $1 b l a_{\mathrm{CTX}-\mathrm{M}-55}$ in a human strain) were found in proximity to ISEcp1. ISEcp1 is a member of the IS1380 family and has previously been associated with ESBL genes [67,68]. A single copy of this IS element is able to mobilize downstream genes through transposition $[69,70]$. De novo assemblies revealed that $m c r-1$ was flanked by IS6 family members in five out of seven carriers. Although assembly scaffold breaks preclude definitive identification of these IS elements, read-mapping identified IS26, a member of the IS6 family, in these strains (three rabbits and two swine). IS26 plays an important role in the evolution and mobilization of ARGs worldwide. These findings suggest a possible involvement of IS26 in the spread of $m c r-1$. Further studies are necessary to establish the precise IS elements involved and their effective ability to transmit $m c r-1$.

Fluoroquinolones and quinolones are important antimicrobials used in both hospital and community settings, with only a minor role in companion and food-producing animals $[37,58]$. Contrastingly, they are reported as some of the most used antimicrobials in poultry and rabbit production systems in Europe [41] despite the European Medicines Agency (EMA) not supplying stratified sales data of veterinary antimicrobials by food-producing animal species [37]. In recent years, there has been a significant increase in fluoroquinolone resistance in human clinical E. coli in Europe, with the highest resistance rates observed in Italy [71]. On the contrary, low resistance to these antimicrobials has been usually observed among livestock in the EU, with the exception of poultry $[12,33]$. In our study, quinolone/fluoroquinolone resistance was mainly identified in poultry (13) and rabbit (15) sources and arose due to chromosomal mutations in gyrA/parC/parE genes. Our findings are in accordance with those previously reported in poultry [33] and rabbits [18] and point to fluoroquinolone usage in these sectors.

Heavy metal resistance genes mer $A$ and ter $A$ identified in the collection are known to be genetically linked to a variety of AMR genes on Tn21- and Tn1721-like transposons (merA) and large MDR IncHI2 plasmids (ter $A)[72,73]$. This likely explains the observation that strains carrying mer $A$ carried more than three times as many ARGs on average ( 7.29 vs. 1.87) compared to the whole collection, whilst five rabbit isolates carrying both merA and ter $A$ had an average of 12.4 ARGs, more than six times the collection average. Environmental heavy metal contamination may, therefore, continue to select for these MDR strains even if antimicrobial use in the sector were to cease.

\subsection{Virulence-Associated Genes}

We identified a surprisingly high number of VAGs (in particular in poultry, rabbit and human niches) despite the fact that our study focused on commensal and environmental E. coli. Furthermore, genetic virulence patterns indicated the presence of potential ExPEC pathotypes. This is rather concerning since E. coli is the most common causative agent of urinary tract infection (UTI) and bloodstream infection (BSI) globally [74,75]. This assumption was strengthened by the identification of different sequence types, recognized as pandemic (ST69, ST95, ST131) [74] or emergent ExPEC lineages (ST10, ST23 ST58, ST117, ST405, ST648) [76]. 
qacE and qacI genes, known to be associated with class 1 integron structure, were identified primarily within intI $1^{+}$sequences [77-80]. qacE and qacI encode small multidrug resistance efflux pump family (SMR) proteins, conferring resistance to quaternary ammonium compounds (QACs), which are commonly used disinfectants in hospitals, healthcare facilities and the food industry [81]. Resistance nodulation division family (RND) efflux pump genes ( $a c r A B, a c r E F, a c r D)$ were also widely identified in the collection. RND family efflux pumps are involved in clinically significant MDR [82] and may target a wide variety of molecules [82-85]. The identification of efflux pump genes could suggest potential phenotypic resistance, where antimicrobial determinants are not identified. However, this event is strictly related to efflux pump overexpression genotypes which we did not evaluate [82].

\section{3. intI1 ${ }^{+}$Strains Carry more ARGs and VAGs}

Class 1 integrons are a reliable proxy for multiple drug resistance gene carriage [86] and play an essential role in the dissemination and evolution of MDR Gram-negative bacteria. As expected, ${ }_{i n t I 1^{+}}$strains carried more ARGs (mean $\left.=8\right)$ than intI1- isolates $($ mean $=1)$. A wide variety of antimicrobial genetic determinants have been identified as intI1 related gene cassettes [87]. In particular, nearly half of the characterized integrons $(15 / 34 ; 44.1 \%)$ carried an aadA1-dfrA1 cassette array. This array is widespread in both commensal and clinical strains isolated from animal and food sources [88]. The most frequent MGEs associated with class 1 integrons in our collection were Tn21 and close relatives, identified in 26 of $35(74.3 \%)$ int $11^{+}$strains. Tn21 transposon and related variants (belonging to the Tn3 family) are globally disseminated and frequently involved in multiple ARGs and class 1 integron carriage in Enterobacteriaceae $[72,89,90]$.

intI $1^{+}$strains carried a higher number of VAGs (mean $\left.=14\right)$ compared with intI1 ${ }^{-}$strains $($mean $=9)$, and often harbored F plasmid replicons. F incompatibility group members are recognized as the majority of virulence-associated plasmids in E. coli. They are known to carry different antimicrobial resistance determinants [91,92] and class 1 integrons [93], creating a concerning combination of virulence and antimicrobial resistance traits. Our findings suggest that ARGs and VAGs may be co-localised on F plasmids in our collection. Long read sequencing data is required to interrogate this hypothesis.

\subsection{Concerning Sources}

Rabbit, poultry and wildlife sources were notable for concerning antimicrobial resistance and virulence profiles. Rabbit represented the niche carrying the highest number of $\mathrm{mcr}-1$ genes ( 3 strains from one animal and two meat samples) among our collection. A recent Italian investigation [94] reported polymyxin (colistin) as a widely used antimicrobial in rabbit farms even though two reports indicated colistin was not a common treatment in rabbit breeding systems [41,95]. Resistance to colistin has been previously reported in breeding rabbits in Europe, supporting the data from the third report [96]. To our knowledge, this is the first report of $m c r-1$ identified in rabbit meat products. This finding suggests rabbit farms and meat should be investigated as a potential reservoir of $m c r-1$ and as a vector for its transmission. Concerningly, eight rabbit strains with ST20 (4/23) and ST40 (4/23) also harbored extensive virulence profiles. These profiles displayed co-presence of both ExPEC and IPEC VAGs and did not correspond to the usual pathotype observed in these lineages. ST20 and ST40 are reported as human diarrheagenic pathogens [97], often producing Shiga toxins [98-100]. The emergence of new hybrid pathotypes could represent a serious threat to public health $[101,102]$, as witnessed in several previous outbreaks $[103,104]$. Further studies are needed to better understand this phenomenon and the potential animal sources involved in hybrid pathotype evolution and diffusion.

Poultry source strains $(11 / 25 ; 44 \%)$ belonged to some of the most prominent ExPEC sequence types (ST131, 1; ST69, 1; ST10, 1; ST23, 3; ST117; 5), all of which were isolated from poultry meat and are previously reported in this niche [25,105-107]. ExPEC lineages carried the highest number of VAGs (mean = 22) among poultry source and a high number of ARGs (mean =5). ST117, a known avian pathogenic extraintestinal E. coli (APEC) lineage and a human pathogen $[25,106,108]$ was 
the most common sequence type among poultry source. Poultry meat is a frequently investigated source of ExPEC E. coli, which can be transmitted to consumers through food consumption [22]. Fecal contamination of poultry carcasses during slaughter could allow potential ExPEC diffusion through the food chain $[109,110]$. Our findings underline the role of poultry as a source of potential ExPEC lineages and the importance of related meat as an ExPEC carrier to humans.

Although wildlife is not as widely scrutinized as food animals for potential threats to human health, a relatively high number of VAGs (mostly associated to ExPEC pathotype) were observed in our wild animal $($ mean $=11)$ and wild boar $($ mean $=8)$ isolates, with 10/47 $(21.3 \%)$ isolates carrying $\geq 15$. Notably, four strains belonged to some of the predominant ExPEC lineages $(2$, ST23; 1, ST117; 1, ST648). The ST648 strain carried the highest number of VAGs (37) in the entire collection. ST648 has been isolated from wild birds [111], humans, surface water, fish, vegetables and companion animals [112,113], has been linked to disease in both human and animals (pets, horses and wildlife) (https://enterobase.warwick.ac.uk/, accessed 19/10/2019) and is frequently reported as an ESBL gene carrier $[113,114]$.

\subsection{Conclusions}

Briefly, our study reaffirmed the role of food-producing animals as a reservoir of potential zoonotic pathogens, with variable antimicrobial and virulence traits among the sources investigated. In particular, rabbits and poultry represented the most concerning sources, carrying the highest number of ARGs and VAGs. Poultry was associated with potential ExPEC strains. Meanwhile, rabbits were a source of potential hybrid E. coli pathogens and carriers of E. coli with mor-1.

It should be noted that our study has two important limitations. Firstly, the small sample size of each source (in particular of companion animals) prevented accurate quantitative comparison between antimicrobial and virulence profiles and the evaluation of possible ARGs and VAGs transmission routes between environments. Secondly, our data originated from short read sequencing analysis. Therefore, we could not determine the location of all ARGs identified and their association with MGEs. Moreover, we were not able to establish similarities/dissimilarities between F plasmids, potentially responsible for VAGs and ARGs carriage in our collection.

Despite these limitations, our study provided basic information about AMR and virulence determinants circulating in various environments in Italy. Further investigations can add a deeper understanding of AMR and virulence epidemiological traits in Gram-negative bacterial populations of different settings.

\section{Materials and Methods}

\subsection{Sampling}

In the period between November 2010 and May 2018 a total of 300 commensal E. coli were collected from 12 different food, animal and human sources (dairy, beef, wild boar, rabbit, poultry, swine, vegetable, fishery, mollusc, wild animal and human), mainly in the Emilia Romagna region of Italy.

Food samples (chicken, rabbit and swine meat products, vegetables and fish) were collected from major supermarkets located in the province of Bologna and from the educational abattoir of the Veterinary Sciences Department (University of Bologna), during slaughtering procedures (sponge of beef carcasses). Milk, cheese and milking system filter samples, collected in a previous study by our research group, were included in the project.

Among animal samples, feces (cat and dog) and cloacal swabs (poultry) were collected from healthy individuals, that had not received antimicrobials in the month prior to the collection. Wild boar diaphragm samples were supplied by Istituto Zooprofilattico Sperimentale della Lombardia e dell'Emilia Romagna (IZSLER), Bologna chapter. 
Collection of human samples were approved by the University of Bologna Bioethics Committee under internal protocol number 0252770 . Human feces were collected from healthy volunteers that were approached for recruitment in person. These participants had not had any antimicrobial treatments in the month prior the collection.

All food, animal and human samples were carried to the laboratory in aseptic conditions and analyzed within two hours from the time of gathering.

IZSLER Bologna, Forlì and Reggio Emilia chapters contributed to the strain collection with 97 hypothetical E. coli, isolated from different animal sources (mollusc, wild animal, rabbit, beef, companion animal, swine). Among these isolates, 12 strains of companion animal origin were isolated from diseased animals and were therefore excluded from the study to avoid the possibility of including pathogens.

The final collection was therefore characterized by $25 \mathrm{E}$. coli for each source (except for companion animal, $\mathrm{n}=13$ ), for a total of 288 strains.

A comprehensive description of the strain collection is provided in Supplementary Material, Table S1.

\subsection{Bacterial Isolation}

Twenty g of food sample (in the case of carcass sponge, each one separately) and wild boar diaphragm were placed into sterile blender bags, diluted in $180 \mathrm{~mL}$ of sterile EC-Broth (Oxoid, Basington, UK) and macerated in a stomacher for $1 \mathrm{~min}$. Samples were incubated overnight at $37 \pm 1^{\circ} \mathrm{C}$. Fecal samples (1 $\mathrm{g}$ each) were diluted (1:10) in peptone water (Oxoid, Basington, UK) and homogenated by vortexing.

Ten $\mu \mathrm{L}$ of overnight culture in EC-Broth (Oxoid, Basington, UK) and $10 \mu \mathrm{L}$ of feces solution (or directly in the case of the cloacal swabs) were streaked onto MacConkey (Oxoid, Basington, UK) and Levine (Oxoid, Basington, UK) agar plates and incubated for $18-24 \mathrm{~h}$ at $37 \pm 1{ }^{\circ} \mathrm{C}$. For all the samples, lactose fermenting colonies were collected and assessed for Gram stain and standard biochemical test (indole probe). E. coli ATCC 25,922 was used as a control strain.

\subsection{Storage}

All strains were freshly cultured on TSA (Oxoid, Basington, UK) for $18-24 \mathrm{~h}$ at $37 \pm 1{ }^{\circ} \mathrm{C}$ and stored at $-80^{\circ} \mathrm{C}$ in cryoprotective medium, composed of Tryptone Soya Broth (Oxoid, Basington, UK) and $20 \%$ glycerol.

\subsection{DNA Extraction and Isolate Identification}

Bacteria were grown from glycerol stocks on Tryptone Soya Agar (TSA) (Oxoid, Basington, UK) plate overnight at $37 \pm 1{ }^{\circ} \mathrm{C}$. Genomic DNA was extracted using a commercial kit (DNeasy Blood and Tissue Kit, Qiagen, Hilden, Germany), following the manufacturer's instruction.

A multiplex PCR targeting four genes (lacY, lacZ, uidA, cyd) was used for E. coli identification, following the method described by Horakova et al. (2008) [115].

The PCR amplification was performed in a reaction volume of $10 \mu \mathrm{L}$ containing $5 \mu \mathrm{L}$ REDExtract-N-Amp PCR ReadyMix (Sigma-Aldrich, St Louis, MO, USA), $0.25 \mu \mathrm{L}$ primers (10 pmol) and $1.5 \mu \mathrm{L}$ DNA.

The following amplification parameters were applied: initial denaturation at $94{ }^{\circ} \mathrm{C}$ for $3 \mathrm{~min}$, 30 cycles of denaturation at $94{ }^{\circ} \mathrm{C}$ for $30 \mathrm{~s}$, annealing at $58^{\circ} \mathrm{C}$ for $25 \mathrm{~s}$, elongation at $72{ }^{\circ} \mathrm{C}$ for $30 \mathrm{~s}$ and a final extension at $72{ }^{\circ} \mathrm{C}$ for $3 \mathrm{~min}$.

The amplified products were loaded onto a $\%$ agarose gel containing Syber Safe DNA Gel Stain (Invitrogen, Carlsbad, CA, USA) and run in 1X TBE buffer at $100 \mathrm{~V}$ for $1 \mathrm{~h}$.

PCR fragments were visualized with a UV transilluminator. A pUC19 DNA/MspI (Hpall) Marker (Thermo Fisher Scientific, Waltham, MA, USA) was loaded on each gel as a DNA size standard. E. coli 
ATCC 25,922 DNA was present in every run as a positive control strain. Strains showing PCR products of $463 \mathrm{bp}, 393 \mathrm{bp}, 319 \mathrm{bp}$ and $264 \mathrm{bp}$ were considered E. coli.

\subsection{WGS and Assembly}

Library preparation was performed using the Nextera Flex library preparation kit (Illumina, San Diego, CA, USA). Briefly, genomic DNA was quantitatively assessed using an Invitrogen Quant-iT picogreen dsDNA assay kit (Thermo Fisher Scientific, Waltham, MA, USA). The sample was then normalized to a concentration of $1 \mathrm{ng} / \mu \mathrm{L}$ and $10 \mathrm{ng}$ of DNA was used for library preparation. After the tagmentation step, DNA was amplified with 12 PCR cycles using the facility's custom designed i7 and i5 barcodes as previously described [59].

Due to the number of samples, the quality control for the samples was done by sequencing a pool of samples using MiSeq V2 nano kit-300 cycles (Illumina, San Diego, CA, USA). Briefly, $3 \mu \mathrm{L}$ of each library was pooled into a library pool, cleaned up using SPRI beads following the Nextera Flex clean up and size selection protocol. The pool was then sequenced using MiSeq V2 nano kit (Illumina, San Diego, CA, USA). Based on the sequencing data generated, the read count for each sample was used to pool libraries at a different amount to ensure equal representation in the final pool and to discard failed libraries (i.e., libraries with less than 100 reads). The final pool was then sequenced on Illumina NextSeq 500, $2 \times 150$ bp at Ramaciotti Centre for Genomics (University of New South Wales, Australia).

Sequence read quality was assessed using FastQC version 0.11 .5 (http://www.bioinformatics. abraham.ac.uk/projects/fastqc/). Illumina raw reads passing quality control were assembled into draft genome sequences using Shovill v1.0.4 with default settings and trimming options (https: //github.com/tseemann/shovill).

Sequencing reads were deposited in the National Center for Biotechnology Information (NCBI) database with study accession number PRJNA528851. Accession numbers for each sample are listed in Supplementary Material, Table S1.

\subsection{Gene Identification, Serotyping, Phylogrouping and Multilocus Sequence Typing}

All gene screening was performed using ARIBA [116] as well as reference sequences from a variety of publicly available databases. Resistance, virulence, plasmid-associated genes and $\mathrm{OH}$ antigen genes were obtained from ResFinder [117], VirulenceFinder [118], PlasmidFinder [119], and SerotypeFinder [120], respectively.

Other sequences of interest (insertion sequence elements, AMR and virulence associated gene sequences), available at https://github.com/maxlcummins/E_coli_customDB and not present within the previous databases were also screened. Moreover, different efflux pump/biocide resistance gene sequences collected from GenBank were considered (Supplementary Material, Table S2). Pointfinder [121] was used to establish chromosomal mutation in $g y r A / B-p a r A / C / E$, ampC and $p m r A / B$, predicting phenotypic resistance to quinolones, AmpC-type cephalosporins and colistin, respectively.

E. coli phylogroups were determined using the Clermont scheme [122], meanwhile the Achtman scheme was used to evaluate E. coli multilocus sequence types (MLST) (http://mlst.warwick.ac.uk/ mlst/). ARIBA results were then processed and summarized with ARIBAlord (https://github.com/ maxlcummins/ARIBAlord).

\subsection{Phylogenetic Analysis}

Maximum-likelihood phylogenetic distances between genomes were analyzed using the PhyloSift pipeline [123], and a tree was generated using FastTree2 [124]. The tree was constructed using FigTree v1.4.4 (http://tree.bio.ed.ac.uk/software/figtree/) and iTOL (https://itol.embl.de/). 
Supplementary Materials: The following are available online at http://www.mdpi.com/2079-6382/9/11/782/s1, Table S1: Metadata, virulence and AMR profile, MGE carriage of the collection Table S2: Efflux pump/biocide database used in the present study, Table S3: Chromosomal mutations identified in the collection, according to Pointfinder analysis, Table S4: Efflux pump/biocide resistant gene carriage.

Author Contributions: Conceptualization, A.S., S.P.D.; methodology, E.M., C.J.R., M.L.C., K.A.; software, C.J.R., M.L.C.; validation, E.M., C.J.R., M.L.C.,T.Z.; formal analysis, E.M., C.J.R., M.L.C.; investigation, E.M., C.J.R.; resources, K.A., A.S., S.P., F.G, S.P.D.; data curation, E.M., C.J.R.; writing-original draft preparation, E.M., C.J.R.; writing-review and editing, E.M., C.J.R., A.S., S.P., F.G., S.P.D.; visualization, E.M., C.J.R., M.L.C., T.Z.; supervision, C.J.R., M.L.C., A.S., S.P.D.; project administration, A.S., S.P.D.; funding acquisition, A.S., S.P.D., T.Z. All authors have read and agreed to the published version of the manuscript.

Funding: This project was supported by the Australian Centre for Genomic Epidemiological Microbiology (AusGEM), a collaborative partnership between the NSW Department of Primary Industries and the University of Technology Sydney.

Acknowledgments: We thank the IZSLER Bologna, Forlì and Reggio Emilia chapters for contributing the E. coli strain collection for this study.

Conflicts of Interest: The authors declare no conflict of interest. The funders had no role in the design of the study; in the collection, analyses, or interpretation of data; in the writing of the manuscript, or in the decision to publish the results.

\section{References}

1. Roca, I.; Akova, M.; Baquero, F.; Carlet, J.; Cavaleri, M.; Coenen, S.; Cohen, J.H.M.; Findlay, D.; Gyssens, I.C.J.; Heure, O.E.; et al. The global threat of antimicrobial resistance: Science for intervention. New Microbes New Infect. 2015, 6, 22-29. [CrossRef] [PubMed]

2. EFSA. ECDC/EFSA/EMA second joint report on the integrated analysis of the consumption of antimicrobial agents and occurrence of antimicrobial resistance in bacteria from humans and food-producing animals. EFSA J. 2017, 15, e04872. [CrossRef]

3. Vila, J.; Sáez-López, E.; Johnson, J.R.; Römling, U.; Dobrindt, U.; Cantón, R.; Giske, C.G.; Naas, T.; Carattoli, A.; Martínez-Medina, M.; et al. Escherichia coli: An old friend with new tidings. FEMS Microbiol. Rev. 2016, 40, 437-463. [CrossRef] [PubMed]

4. Van Schaik, W. The human gut resistome. Philos. Trans. R. Soc. B Biol. Sci. 2015, 370, 20140087. [CrossRef] [PubMed]

5. Madec, J.-Y.; Haenni, M. Antimicrobial resistance plasmid reservoir in food and food-producing animals. Plasmid 2018, 99, 72-81. [CrossRef]

6. Ewers, C.; Bethe, A.; Semmler, T.; Guenther, S.; Wieler, L.H. Extended-spectrum beta-lactamase-producing and AmpC-producing Escherichia coli from livestock and companion animals, and their putative impact on public health: A global perspective. Clin. Microbiol. Infect. 2012, 18, 646-655. [CrossRef]

7. Djordjevic, S.P.; Stokes, H.W.; Chowdhury, P.R. Mobile elements, zoonotic pathogens and commensal bacteria: Conduits for the delivery of resistance genes into humans, production animals and soil microbiota. Front. Microbiol. 2013, 4, 86. [CrossRef]

8. Singer, A.C.; Shaw, H.; Rhodes, V.; Hart, A. Review of Antimicrobial Resistance in the Environment and Its Relevance to Environmental Regulators. Front. Microbiol. 2016, 7, 1728. [CrossRef]

9. European Commission. Commission Implementing Decision (EU) 2018/945 of 22 June 2018 on the communicable diseases and related special health issues to be covered by epidemiological surveillance as well as relevant case definitions. Official Journal of the European Union, 2018, L170/1. Available online: https: //eur-lex.europa.eu/legal-content/EN/TXT/PDF/?uri=CELEX:32018D0945 (accessed on 10 September 2020).

10. Kaper, J.B.; Nataro, J.P.; Mobley, H.L. Pathogenic escherichia coli. Nat. Rev. Microbiol. 2004, 2, 123. [CrossRef]

11. Jang, J.; Hur, H.-G.; Sadowsky, M.; Byappanahalli, M.; Yan, T.; Ishii, S. EnvironmentalEscherichia coli: Ecology and public health implications-a review. J. Appl. Microbiol. 2017, 123, 570-581. [CrossRef] [PubMed]

12. EFSA. The European Union summary report on antimicrobial resistance in zoonotic and indicator bacteria from humans, animals and food in 2017. EFSA J. 2019, 17, e05598. [CrossRef]

13. Bourély, C.; Coeffic, T.; Caillon, J.; Thibaut, S.; Cazeau, G.; Jouy, E.; Jarrige, N.; Chauvin, C.; Madec, J.-Y.; Haenni, M.; et al. Trends in antimicrobial resistance among Escherichia coli from defined infections in humans and animals. J. Antimicrob. Chemother. 2020, 75, 1525-1529. [CrossRef] 
14. Alqasim, A.; Abu Jaffal, A.; Alyousef, A.A. Prevalence of Multidrug Resistance and Extended-Spectrum $\beta$-Lactamase Carriage of Clinical Uropathogenic Escherichia coli Isolates in Riyadh, Saudi Arabia. Int. J. Microbiol. 2018, 2018, 3026851-3026859. [CrossRef]

15. Wang, S.; Zhao, S.-Y.; Xiao, S.-Z.; Gu, F.-F.; Liu, Q.-Z.; Tang, J.; Guo, X.-K.; Ni, Y.-X.; Han, L.-Z. Antimicrobial Resistance and Molecular Epidemiology of Escherichia coli Causing Bloodstream Infections in Three Hospitals in Shanghai, China. PLoS ONE 2016, 11, e0147740. [CrossRef]

16. Chalmers, G.; Cormier, A.C.; Nadeau, M.; Côté, G.; Reid-Smith, R.J.; Boerlin, P. Determinants of virulence and of resistance to ceftiofur, gentamicin, and spectinomycin in clinical Escherichia coli from broiler chickens in Québec, Canada. Vet. Microbiol. 2017, 203, 149-157. [CrossRef]

17. Bortolaia, V.; Guardabassi, L.; Trevisani, M.; Bisgaard, M.; Venturi, L.; Bojesen, A.M. High Diversity of Extended-Spectrum $\beta$-Lactamases in Escherichia coli Isolates from Italian Broiler Flocks. Antimicrob. Agents Chemother. 2010, 54, 1623-1626. [CrossRef] [PubMed]

18. Dotto, G.; Giacomelli, M.; Grilli, G.; Ferrazzi, V.; Carattoli, A.; Fortini, D.; Piccirillo, A. High Prevalence of oqxAB in Escherichia coli Isolates from Domestic and Wild Lagomorphs in Italy. Microb. Drug Resist. 2014, 20, 118-123. [CrossRef]

19. El Garch, F.; De Jong, A.; Bertrand, X.; Hocquet, D.; Sauget, M. mcr-1-like detection in commensal Escherichia coli and Salmonella spp. from food-producing animals at slaughter in Europe. Vet. Microbiol. 2018, 213, 42-46. [CrossRef] [PubMed]

20. Ghodousi, A.; Bunora, C.; Di Noto, A.M.; Mammina, C. Extended-Spectrum ss-Lactamase, AmpC-Producing, and Fluoroquinolone-Resistant Escherichia coli in Retail Broiler Chicken Meat, Italy. Foodborne Pathog. Dis. 2015, 12, 619-625. [CrossRef]

21. Hastak, P.; Cummins, M.L.; Gottlieb, T.; Cheong, E.; Merlino, J.; Myers, G.S.A.; Djordjevic, S.P.; Chowdhury, P.R. Genomic profiling of Escherichia coli isolates from bacteraemia patients: A 3-year cohort study of isolates collected at a Sydney teaching hospital. Microb. Genom. 2020, 6, e000371. [CrossRef]

22. Liu, C.M.; Stegger, M.; Aziz, M.; Johnson, T.J.; Waits, K.; Nordstrom, L.; Gauld, L.; Weaver, B.; Rolland, D.; Statham, S.; et al. Escherichia coli ST131-H22 as a Foodborne Uropathogen. mBio 2018, 9, e00470-18. [CrossRef]

23. Ludden, C.; Raven, K.E.; Jamrozy, D.; Gouliouris, T.; Blane, B.; Coll, F.; De Goffau, M.; Naydenova, P.; Horner, C.; Hernandez-Garcia, J.; et al. One Health Genomic Surveillance of Escherichia coli Demonstrates Distinct Lineages and Mobile Genetic Elements in Isolates from Humans versus Livestock. mBio 2019, 10 , e02693-18. [CrossRef]

24. Cordoni, G.; Woodward, M.J.; Wu, H.; Alanazi, M.; Wallis, T.; La Ragione, R.M. Comparative genomics of European avian pathogenic E. Coli (APEC). BMC Genom. 2016, 17, 1-21. [CrossRef] [PubMed]

25. Cummins, M.L.; Reid, C.J.; Chowdhury, P.R.; Bushell, R.N.; Esbert, N.; Tivendale, K.A.; Noormohammadi, A.H.; Islam, S.; Marenda, M.S.; Browning, G.F.; et al. Whole genome sequence analysis of Australian avian pathogenic Escherichia coli that carry the class 1 integrase gene. Microb. Genom. 2019, 5. [CrossRef] [PubMed]

26. Reid, C.J.; Blau, K.; Jechalke, S.; Smalla, K.; Djordjevic, S.P. Whole Genome Sequencing of Escherichia coli From Store-Bought Produce. Front. Microbiol. 2019, 10, 3050. [CrossRef]

27. Manageiro, V.; Jones-Dias, D.; Ferreira, E.; Caniça, M. Plasmid-Mediated Colistin Resistance (mcr-1) in Escherichia coli from Non-Imported Fresh Vegetables for Human Consumption in Portugal. Microorganisms 2020, 8, 429. [CrossRef]

28. Marchetti, V.M.; Bitar, I.; Mercato, A.; Nucleo, E.; Marchesini, F.; Mancinelli, M.; Prati, P.; Scarsi, G.S.; Hrabak, J.; Pagani, L.; et al. Deadly Puppy Infection Caused by an MDR Escherichia coli O39 blaCTX-M-15, blaCMY-2, blaDHA-1, and aac(6)-Ib-cr-Positive in a Breeding Kennel in Central Italy. Front. Microbiol. 2020, 11, 584. [CrossRef]

29. Mora, A.; García-Peña, F.J.; Alonso, M.P.; Pedraza-Diaz, S.; Ortega-Mora, L.M.; Garcia-Parraga, D.; López, C.; Viso, S.; Dahbi, G.; Marzoa, J.; et al. Impact of human-associated Escherichia coli clonal groups in Antarctic pinnipeds: Presence of ST73, ST95, ST141 and ST131. Sci. Rep. 2018, 8, 1-11. [CrossRef]

30. Raven, K.E.; Ludden, C.; Gouliouris, T.; Blane, B.; Naydenova, P.; Brown, N.M.; Parkhill, J.; Peacock, S.J. Genomic surveillance of Escherichia coli in municipal wastewater treatment plants as an indicator of clinically relevant pathogens and their resistance genes. Microb. Genom. 2019, 5, e000267. [CrossRef] 
31. Furlan, J.P.R.; Savazzi, E.A.; Stehling, E.G. Widespread high-risk clones of multidrug-resistant extended-spectrum beta-lactamase-producing Escherichia coli B2-ST131 and F-ST648 in public aquatic environments. Int. J. Antimicrob. Agents 2020, 56, 106040. [CrossRef]

32. Eguenther, S.; Ewers, C.; Wieler, L.H. Extended-Spectrum Beta-Lactamases Producing E. coli in Wildlife, yet Another Form of Environmental Pollution? Front. Microbiol. 2011, 2, 246. [CrossRef]

33. EFSA. The European Union summary report on antimicrobial resistance in zoonotic and indicator bacteria from humans, animals and food in 2016. EFSA J. 2018, 16, e05182. [CrossRef]

34. Bailey, J.K.; Pinyon, J.L.; Anantham, S.; Hall, R.M. Commensal Escherichia coli of healthy humans: A reservoir for antibiotic-resistance determinants. J. Med. Microbiol. 2010, 59, 1331-1339. [CrossRef] [PubMed]

35. Grevskott, D.H.; Svanevik, C.S.; Sunde, M.; Wester, A.L.; Lunestad, B.T. Marine Bivalve Mollusks As Possible Indicators of Multidrug-Resistant Escherichia coli and Other Species of the Enterobacteriaceae Family. Front. Microbiol. 2017, 8, 24. [CrossRef]

36. Holvoet, K.; Sampers, I.; Callens, B.; Dewulf, J.; Uyttendaele, M. Moderate Prevalence of Antimicrobial Resistance in Escherichia coli Isolates from Lettuce, Irrigation Water, and Soil. Appl. Environ. Microbiol. 2013, 79, 6677-6683. [CrossRef]

37. EMA. European Surveillance of Veterinary Antimicrobial Consumption (ESVAC). 2019. Available online: https://www.ema.europa.eu/en/veterinary-regulatory/overview/antimicrobial-resistance/europeansurveillance-veterinary-antimicrobial-consumption-esvac (accessed on 2 October 2019).

38. Sousa, M.; Torres, C.; Barros, J.; Somalo, S.; Igrejas, G.; Poeta, P. Gilthead Seabream (Sparus aurata) as Carriers of SHV-12 and TEM-52 Extended-Spectrum Beta-Lactamases-Containing Escherichia coli Isolates. Foodborne Pathog. Dis. 2011, 8, 1139-1141. [CrossRef]

39. Campos, J.; Mourão, J.; Pestana, N.; Peixe, L.; Novais, C.; Antunes, P. Microbiological quality of ready-to-eat salads: An underestimated vehicle of bacteria and clinically relevant antibiotic resistance genes. Int. J. Food Microbiol. 2013, 166, 464-470. [CrossRef]

40. Jensen, A.N.; Storm, C.; Forslund, A.; Baggesen, D.L.; Dalsgaard, A. Escherichia coli Contamination of Lettuce Grown in Soils Amended with Animal Slurry. J. Food Prot. 2013, 76, 1137-1144. [CrossRef]

41. FVE. Antimicrobial use in food-producing animals. Replies to EFSA/EMA questions on the use of antimicrobials in food-producing animals in EU and possible measures to reduce antimicrobial use. 2016. Available online: https://www.ema.europa.eu (accessed on 10 September 2020).

42. Literák, I.; Dolejska, M.; Radimersky, T.; Klimes, J.; Friedman, M.; Aarestrup, F.M.; Hasman, H.; Cizek, A. Antimicrobial-resistant faecal Escherichia coliin wild mammals in central Europe: Multiresistant Escherichia coliproducing extended-spectrum beta-lactamases in wild boars. J. Appl. Microbiol. 2010, 108, 1702-1711. [CrossRef]

43. Giacopello, C.; Foti, M.; Mascetti, A.; Grosso, F.; Ricciardi, D.; Fisichella, V.; Piccolo, F.L. Antimicrobial resistance patterns of Enterobacteriaceae in European wild bird species admitted in a wildlife rescue centre. Vet. Ital. 2016, 52, 139-144. [PubMed]

44. Dolejska, M.; Cizek, A.; Literak, I. High prevalence of antimicrobial-resistant genes and integrons in Escherichia coli isolates from Black-headed Gulls in the Czech Republic. J. Appl. Microbiol. 2007, 103, 11-19. [CrossRef]

45. Furness, L.E.; Campbell, A.; Zhang, L.; Gaze, W.H.; McDonald, R.A. Wild small mammals as sentinels for the environmental transmission of antimicrobial resistance. Environ. Res. 2017, 154, 28-34. [CrossRef] [PubMed]

46. Skurnik, D.; Ruimy, R.; Andremont, A.; Amorin, C.; Rouquet, P.; Picard, B.; Denamur, E. Effect of human vicinity on antimicrobial resistance and integrons in animal faecal Escherichia coli. J. Antimicrob. Chemother. 2006, 57, 1215-1219. [CrossRef] [PubMed]

47. Allen, H.K.; Donato, J.; Wang, H.H.; Cloud-Hansen, K.A.; Davies, J.; Handelsman, J. Call of the wild: Antibiotic resistance genes in natural environments. Nat. Rev. Genet. 2010, 8, 251-259. [CrossRef]

48. Wyrsch, E.R.; Chowdhury, P.R.; Chapman, T.A.; Charles, I.G.; Hammond, J.M.; Djordjevic, S.P. Genomic Microbial Epidemiology Is Needed to Comprehend the Global Problem of Antibiotic Resistance and to Improve Pathogen Diagnosis. Front. Microbiol. 2016, 7, 843. [CrossRef] [PubMed]

49. Smalla, K.; Cook, K.; Djordjevic, S.P.; Klümper, U.; Gillings, M.R. Environmental dimensions of antibiotic resistance: Assessment of basic science gaps. FEMS Microbiol. Ecol. 2018, 94. [CrossRef]

50. Walczak, J.J.; Xu, S. Manure as a Source of Antibiotic-Resistant Escherichia coli and Enterococci: A Case Study of a Wisconsin, USA Family Dairy Farm. Water Air Soil Pollut. 2011, 219, 579-589. [CrossRef] 
51. Alves, M.S.; Pereira, A.; Araujo, S.M.; Castro, B.B.; Correia, A.C.M.; Henriques, I. Seawater is a reservoir of multi-resistant Escherichia coli, including strains hosting plasmid-mediated quinolones resistance and extended-spectrum beta-lactamases genes. Front. Microbiol. 2014, 5, 426. [CrossRef]

52. Martinez, J.L. Environmental pollution by antibiotics and by antibiotic resistance determinants. Environ. Pollut. 2009, 157, 2893-2902. [CrossRef]

53. Balière, C.; Erincé, A.; Eblanco, J.; Edahbi, G.; Eharel, J.; Evogeleer, P.; Egiard, J.-C.; Mariani-Kurkdjian, P.; Gourmelon, M. Prevalence and Characterization of Shiga Toxin-Producing and Enteropathogenic Escherichia coli in Shellfish-Harvesting Areas and Their Watersheds. Front. Microbiol. 2015, 6, 1356. [CrossRef]

54. Costa, D.; Poeta, P.; Sáenz, Y.; Vinué, L.; Coelho, A.; Matos, M.; Rojo-Bezares, B.; Rodrigues, J.; Torres, C. Mechanisms of Antibiotic Resistance inEscherichia coliIsolates Recovered from Wild Animals. Microb. Drug Resist. 2008, 14, 71-77. [CrossRef]

55. Skurnik, D.; Bonnet, D.; Bernde-Bauduin, C.; Michel, R.; Guette, C.; Becker, J.-M.; Balaire, C.; Chau, F.; Mohler, J.; Jarlier, V.; et al. Characteristics of human intestinalEscherichia coliwith changing environments. Environ. Microbiol. 2008, 10, 2132-2137. [CrossRef]

56. EFSA. The European Union summary report on antimicrobial resistance in zoonotic and indicator bacteria from humans, animals and food in 2014. EFSA J. 2016, 14, 4380. [CrossRef]

57. EFSA. The European Union summary report on antimicrobial resistance in zoonotic and indicator bacteria from humans, animals and food in 2015. EFSA J. 2017, 15, e04694. [CrossRef]

58. ECDC. Antimicrobial consumption. Annual epidemiological report for 2017. 2018. Available online: https://www. ecdc.europa.eu/en/publications-data/antimicrobial-consumption-annual-epidemiological-report-2017 (accessed on 10 September 2020).

59. Reid, C.J.; Wyrsch, E.R.; Chowdhury, P.R.; Zingali, T.; Liu, M.; Darling, A.E.; Chapman, T.A.; Djordjevic, S.P. Porcine commensal Escherichia coli: A reservoir for class 1 integrons associated with IS26. Microb. Genom. 2017, 3. [CrossRef]

60. Pezzella, C.; Ricci, A.; Digiannatale, E.; Luzzi, I.; Carattoli, A. Tetracycline and Streptomycin Resistance Genes, Transposons, and Plasmids in Salmonella enterica Isolates from Animals in Italy. Antimicrob. Agents Chemother. 2004, 48, 903-908. [CrossRef]

61. Reid, C.J.; Chowdhury, P.R.; Djordjevic, S.P. Tn6026 and Tn6029 are found in complex resistance regions mobilised by diverse plasmids and chromosomal islands in multiple antibiotic resistant Enterobacteriaceae. Plasmid 2015, 80, 127-137. [CrossRef]

62. Rozwandowicz, M.; Brouwer, M.S.M.; Fischer, J.; A Wagenaar, J.; Gonzalez-Zorn, B.; Guerra, B.; Mevius, D.J.; Hordijk, J. Plasmids carrying antimicrobial resistance genes in Enterobacteriaceae. J. Antimicrob. Chemother. 2018, 73, 1121-1137. [CrossRef] [PubMed]

63. Enne, V.I.; Bennett, P.M.; Livermore, D.M.; Hall, L.M.C. Enhancement of host fitness by the sul2-coding plasmid p9123 in the absence of selective pressure. J. Antimicrob. Chemother. 2004, 53, 958-963. [CrossRef]

64. Yau, S.; Liu, X.; Djordjevic, S.P.; Hall, R.M. RSF1010-Like Plasmids in AustralianSalmonella entericaSerovar Typhimurium and Origin of Theirsul2-strA-strBAntibiotic Resistance Gene Cluster. Microb. Drug Resist. 2010, 16, 249-252. [CrossRef]

65. Maciuca, I.E.; Cummins, M.L.; Cozma, A.P.; Rimbu, C.M.; Guguianu, E.; Panzaru, C.; Licker, M.; Szekely, E.; Flonta, M.; Djordjevic, S.P.; et al. Genetic Features of mcr-1 Mediated Colistin Resistance in CMY-2-Producing Escherichia coli From Romanian Poultry. Front. Microbiol. 2019, 10, 2267. [CrossRef]

66. Quesada, A.; Ugarte-Ruiz, M.; Iglesias, M.R.; Porrero, M.C.; Martínez, R.; Florez-Cuadrado, D.; Campos, M.J.; García, M.; Píriz, S.; Sáez, J.L.; et al. Detection of plasmid mediated colistin resistance (MCR-1) in Escherichia coli and Salmonella enterica isolated from poultry and swine in Spain. Res. Vet. Sci. 2016, 105, 134-135. [CrossRef]

67. Lartigue, M.-F.; Poirel, L.; Nordmann, P. Diversity of genetic environment of bla CTX-M genes. FEMS Microbiol. Lett. 2006, 234, 201-207. [CrossRef]

68. Dhanji, H.; Doumith, M.; Hope, R.; Livermore, D.M.; Woodford, N. IS Ecp1-mediated transposition of linked bla CTX-M-3 and bla TEM-1b from the IncI1 plasmid pEK204 found in clinical isolates of Escherichia coli from Belfast, UK. J. Antimicrob. Chemother. 2011, 66, 2263-2265. [CrossRef]

69. Poirel, L.; Decousser, J.-W.; Nordmann, P. Insertion Sequence ISEcp1B Is Involved in Expression and Mobilization of a blaCTX-M $\beta$-Lactamase Gene. Antimicrob. Agents Chemother. 2003, 47, 2938-2945. [CrossRef] 
70. Poirel, L.; Naas, T.; Nordmann, P. Genetic support of extended-spectrum $\beta$-lactamases. Clin. Microbiol. Infect. 2008, 14, 75-81. [CrossRef]

71. ECDC. ECDC Surveillance Report. Surveillance of antimicrobial resistance in Europe 2017. 2018. Available online: https:/ecdc.europa.eu/en/publications-data/surveillance-antimicrobial-resistance-europe-2017 (accessed on 10 September 2020).

72. Liebert, C.A.; Hall, R.M.; Summers, A.O. Transposon Tn21, Flagship of the Floating Genome. Microbiol. Mol. Biol. Rev. 1999, 63, 507-522. [CrossRef] [PubMed]

73. Wyrsch, E.R.; Reid, C.J.; DeMaere, M.Z.; Liu, M.Y.; Chapman, T.A.; Chowdhury, P.R.; Djordjevic, S.P. Complete Sequences of Multiple-Drug Resistant IncHI2 ST3 Plasmids in Escherichia coli of Porcine Origin in Australia. Front. Sustain. Food Syst. 2019, 3. [CrossRef]

74. Riley, L.W. Pandemic lineages of extraintestinal pathogenic Escherichia coli. Clin. Microbiol. Infect. 2014, 20, 380-390. [CrossRef]

75. Poolman, J.T.; Wacker, M. Extraintestinal PathogenicEscherichia coli, a Common Human Pathogen: Challenges for Vaccine Development and Progress in the Field. J. Infect. Dis. 2016, 213, 6-13. [CrossRef]

76. Manges, A.R.; Geum, H.M.; Guo, A.; Edens, T.J.; Fibke, C.D.; Pitout, J.D.D. Global Extraintestinal Pathogenic Escherichia coli (ExPEC) Lineages. Clin. Microbiol. Rev. 2019, 32, e00135-18. [CrossRef]

77. Gaze, W.H.; Abdouslam, N.; Hawkey, P.M.; Wellington, E.M.H. Incidence of Class 1 Integrons in a Quaternary Ammonium Compound-Polluted Environment. Antimicrob. Agents Chemother. 2005, 49, 1802-1807. [CrossRef]

78. Romero, J.L.; Burgos, M.J.G.; Pérez-Pulido, R.; Gálvez, A.; Lucas, R. Resistance to Antibiotics, Biocides, Preservatives and Metals in Bacteria Isolated from Seafoods: Co-Selection of Strains Resistant or Tolerant to Different Classes of Compounds. Front. Microbiol. 2017, 8, 1650. [CrossRef]

79. Soufi, L.; Abbassi, M.S.; Sáenz, Y.; Vinué, L.; Somalo, S.; Zarazaga, M.; Abbas, A.; Dbaya, R.; Khanfir, L.; Ben Hassen, A.; et al. Prevalence and Diversity of Integrons and Associated Resistance Genes inEscherichia coliIsolates from Poultry Meat in Tunisia. Foodborne Pathog. Dis. 2009, 6, 1067-1073. [CrossRef]

80. Wannaprasat, W.; Padungtod, P.; Chuanchuen, R. Class 1 integrons and virulence genes in Salmonella enterica isolates from pork and humans. Int. J. Antimicrob. Agents 2011, 37, 457-461. [CrossRef]

81. Gerba, C.P. Quaternary Ammonium Biocides: Efficacy in Application. Appl. Environ. Microbiol. 2014, 81, 464-469. [CrossRef]

82. Piddock, L.J.V. Multidrug-resistance efflux pumps? not just for resistance. Nat. Rev. Genet. 2006, 4, 629-636. [CrossRef] [PubMed]

83. Rosenberg, E.Y.; Ma, D.; Nikaido, H. AcrD of Escherichia coli Is an Aminoglycoside Efflux Pump. J. Bacteriol. 2000, 182, 1754-1756. [CrossRef]

84. Nishino, K.; Yamagchi, A. Analysis of a Complete Library of Putative Drug Transporter Genes in Escherichia coli. J. Bacteriol. 2001, 183, 5803-5812. [CrossRef]

85. Nagakubo, S.; Nishino, K.; Hirata, T.; Yamaguchi, A. The Putative Response Regulator BaeR Stimulates Multidrug Resistance of Escherichia coli via a Novel Multidrug Exporter System, MdtABC. J. Bacteriol. 2002, 184, 4161-4167. [CrossRef]

86. Gillings, M.R.; Gaze, W.H.; Pruden, A.; Smalla, K.; Tiedje, J.M.; Zhu, Y.-G. Using the class 1 integron-integrase gene as a proxy for anthropogenic pollution. ISME J. 2015, 9, 1269-1279. [CrossRef]

87. Partridge, S.R.; Tsafnat, G.; Coiera, E.; Iredell, J.R. Gene cassettes and cassette arrays in mobile resistance integrons. FEMS Microbiol. Rev. 2009, 33, 757-784. [CrossRef]

88. Kaushik, M.; Kumar, S.; Kapoor, R.K.; Virdi, J.S.; Gulati, P. Integrons in Enterobacteriaceae: Diversity, distribution and epidemiology. Int. J. Antimicrob. Agents 2018, 51, 167-176. [CrossRef]

89. Partridge, S.R.; Kwong, S.M.; Firth, N.; Jensen, S.O. Mobile Genetic Elements Associated with Antimicrobial Resistance. Clin. Microbiol. Rev. 2018, 31, e00088-17. [CrossRef] [PubMed]

90. Dawes, F.E.; Kuzevski, A.; Bettelheim, K.A.; Hornitzky, M.A.; Djordjevic, S.P.; Walker, M.J. Distribution of Class 1 Integrons with IS26-Mediated Deletions in Their 3'-Conserved Segments in Escherichia coli of Human and Animal Origin. PLoS ONE 2010, 5, e12754. [CrossRef] [PubMed]

91. Johnson, T.J.; Nolan, L.K. Pathogenomics of the Virulence Plasmids of Escherichia coli. Microbiol. Mol. Biol. Rev. 2009, 73, 750-774. [CrossRef] [PubMed]

92. Da Silva, G.J.; Mendonça, N. Association between antimicrobial resistance and virulence in Escherichia coli. Virulence 2012, 3, 18-28. [CrossRef] 
93. Moura, A.; Oliveira, C.; Henriques, I.; Smalla, K.; Correia, A. Broad diversity of conjugative plasmids in integron-carrying bacteria from wastewater environments. FEMS Microbiol. Lett. 2012, 330, 157-164. [CrossRef]

94. Agnoletti, F.; Brunetta, R.; Bano, L.; Drigo, I.; Mazzolini, E. Longitudinal study on antimicrobial consumption and resistance in rabbit farming. Int. J. Antimicrob. Agents 2018, 51, 197-205. [CrossRef]

95. SSR-ER. Uso degli antimicrobici negli animali da produzione. Limiti delle ricette veterinarie per attività di farmacosorveglianza. 2006. Available online: https://assr.regione.emilia-romagna.it (accessed on 10 September 2020).

96. Freitas-Silva, J.; Inácio, Â.; Mourão, J.; Antunes, P.; Mendes, Â.; De Carvalho, A.P.; Vasconcelos, V.M.; Peixe, L.; Da Costa, P.M. Occurrence of mcr-1 in Escherichia coli from rabbits of intensive farming. Vet. Microbiol. 2018, 227, 78-81. [CrossRef]

97. Yu, F.; Chen, X.; Zheng, S.; Han, D.; Wang, Y.; Wang, R.; Wang, B.; Chen, Y. Prevalence and genetic diversity of human diarrheagenic Escherichia coli isolates by multilocus sequence typing. Int. J. Infect. Dis. 2018, 67, 7-13. [CrossRef] [PubMed]

98. Prager, R.; Fruth, A.; Siewert, U.; Strutz, U.; Tschäpe, H. Escherichia coli encoding Shiga toxin $2 \mathrm{f}$ as an emerging human pathogen. Int. J. Med Microbiol. 2009, 299, 343-353. [CrossRef] [PubMed]

99. Fierz, L.; Cernela, L.; Hauser, E.; Nuesch-Inderbinen, M.; Stephan, R. Characteristics of Shigatoxin-producing Escherichia coli strains isolated during 2010-2014 from human infections in Switzerland. Front. Microbiol. 2017, 8, 1471. [CrossRef]

100. Van Hoek, A.H.A.M.; Van Veldhuizen, J.N.J.; Friesema, I.; Coipan, E.C.; Rossen, J.W.A.; Bergval, I.L.; Franz, E. Comparative genomics reveals a lack of evidence for pigeons as a main source of stx2f-carrying Escherichia coli causing disease in humans and the common existence of hybrid Shiga toxin-producing and enteropathogenic E. coli pathotypes. BMC Genom. 2019, 20, 271. [CrossRef]

101. Soysal, N.; Mariani-Kurkdjian, P.; Smail, Y.; Liguori, S.; Gouali, M.; Loukiadis, E.; Fach, P.; Bruyand, M.; Blanco, J.; Bidet, P.; et al. EnterohemorrhagicEscherichia coliHybrid Pathotype O80:H2 as a New Therapeutic Challenge. Emerg. Infect. Dis. 2016, 22, 1604-1612. [CrossRef]

102. Jarocki, V.M.; Reid, C.J.; Chapman, T.A.; Djordjevic, S.P. Escherichia coli ST302: Genomic Analysis of Virulence Potential and Antimicrobial Resistance Mediated by Mobile Genetic Elements. Front. Microbiol. 2019, 10, 3098. [CrossRef] [PubMed]

103. Bielaszewska, M.; Mellmann, A.; Zhang, W.; Köck, R.; Fruth, A.; Bauwens, A.; Peters, G.; Karch, H. Characterisation of the Escherichia coli strain associated with an outbreak of haemolytic uraemic syndrome in Germany, 2011: A microbiological study. Lancet Infect. Dis. 2011, 11, 671-676. [CrossRef]

104. Lindstedt, B.-A.; Finton, M.D.; Porcellato, D.; Brandal, L.T. High frequency of hybrid Escherichia coli strains with combined Intestinal Pathogenic Escherichia coli (IPEC) and Extraintestinal Pathogenic Escherichia coli (ExPEC) virulence factors isolated from human faecal samples. BMC Infect. Dis. 2018, 18, 1-12. [CrossRef]

105. Cortés, P.; Blanc, V.; Mora, A.; Dahbi, G.; Blanco, J.E.; Blanco, M.; López, C.; Andreu, A.; Navarro, F.; Alonso, M.P.; et al. Isolation and Characterization of Potentially Pathogenic Antimicrobial-Resistant Escherichia coli Strains from Chicken and Pig Farms in Spain. Appl. Environ. Microbiol. 2010, 76, 2799-2805. [CrossRef]

106. Hall, M.L.-V.; Dierikx, C.; Stuart, J.C.; Voets, G.; Munckhof, M.V.D.; Van Essen-Zandbergen, A.; Platteel, T.; Fluit, A.; Van De Sande-Bruinsma, N.; Scharinga, J.; et al. Dutch patients, retail chicken meat and poultry share the same ESBL genes, plasmids and strains. Clin. Microbiol. Infect. 2011, 17, 873-880. [CrossRef]

107. Manges, A.R.; Johnson, J.R. Food-Borne Origins of Escherichia coli Causing Extraintestinal Infections. Clin. Infect. Dis. 2012, 55, 712-719. [CrossRef]

108. Mora, A.; López, C.; Herrera, A.; Viso, S.; Mamani, R.; Dhabi, G.; Alonso, M.P.; Blanco, M.; Blanco, J.E.; Blanco, J. Emerging avian pathogenic Escherichia coli strains belonging to clonal groups O111:H4-D-ST2085 and O111:H4-D-ST117 with high virulence-gene content and zoonotic potential. Vet. Microbiol. 2012, 156, 347-352. [CrossRef]

109. Mor-Mur, M.; Yuste, J. Emerging Bacterial Pathogens in Meat and Poultry: An Overview. Food Bioprocess Technol. 2009, 3, 24-35. [CrossRef]

110. Lyhs, U.; Ikonen, I.; Pohjanvirta, T.; Raninen, K.; Perko-Mäkelä, P.; Pelkonen, S. Extraintestinal pathogenic Escherichia coli in poultry meat products on the Finnish retail market. Acta Vet. Scand. 2012, 54, 64. [CrossRef] 
111. Guenther, S.; Grobbel, M.; Beutlich, J.; Bethe, A.; Friedrich, N.D.; Goedecke, A.; Lubke-Becker, A.; Guerra, B.; Wieler, L.H.; Ewers, C. CTX-M-15-type extended-spectrum beta-lactamases-producing Escherichia coli from wild birds in Germany. Environ. Microbiol. Rep 2010, 2, 641-645. [CrossRef]

112. Ewers, C.; Bethe, A.; Stamm, I.; Grobbel, M.; Kopp, P.A.; Guerra, B.; Stubbe, M.; Doi, Y.; Zong, Z.; Kola, A.; et al. CTX-M-15-D-ST648 Escherichia coli from companion animals and horses: Another pandemic clone combining multiresistance and extraintestinal virulence? J. Antimicrob. Chemother. 2014, 69, 1224-1230. [CrossRef]

113. Müller, A.; Stephan, R.; Nüesch-Inderbinen, M. Distribution of virulence factors in ESBL-producing Escherichia coli isolated from the environment, livestock, food and humans. Sci. Total. Environ. 2016, 541, 667-672. [CrossRef]

114. Cortés-Cortés, G.; Lozano-Zarain, P.; Torres, C.; Castañeda, M.; Sánchez, G.M.; Alonso, C.A.; López-Pliego, L.; Mayen, M.G.G.; Martínez-Laguna, Y.; Rocha-Gracia, R.D.C. Detection and Molecular Characterization ofEscherichia coliStrains Producers of Extended-Spectrum and CMY-2 Type Beta-Lactamases, Isolated from Turtles in Mexico. Vector-Borne Zoonotic Dis. 2016, 16, 595-603. [CrossRef]

115. Horakova, K.; Mlejnkova, H.; Mlejnek, P. Specific detection of Escherichia coli isolated from water samples using polymerase chain reaction targeting four genes: Cytochrome bd complex, lactose permease, beta-D-glucuronidase, and beta-D-galactosidase. J. Appl. Microbiol. 2008, 105, 970-976. [CrossRef] [PubMed]

116. Hunt, M.; E Mather, A.; Sánchez-Busó, L.; Page, A.J.; Parkhill, J.; A Keane, J.; Harris, S.R. ARIBA: Rapid antimicrobial resistance genotyping directly from sequencing reads. Microb. Genom. 2017, 3, e000131. [CrossRef]

117. Zankari, E.; Hasman, H.; Cosentino, S.; Vestergaard, M.; Rasmussen, S.; Lund, O.; Aarestrup, F.M.; Larsen, M.V. Identification of acquired antimicrobial resistance genes. J. Antimicrob. Chemother. 2012, 67, 2640-2644. [CrossRef]

118. Joensen, K.G.; Scheutz, F.; Lund, O.; Hasman, H.; Kaas, R.S.; Nielsen, E.M.; Aarestrup, F.M. Real-Time Whole-Genome Sequencing for Routine Typing, Surveillance, and Outbreak Detection of Verotoxigenic Escherichia coli. J. Clin. Microbiol. 2014, 52, 1501-1510. [CrossRef]

119. Carattoli, A.; Zankari, E.; García-Fernández, A.; Larsen, M.V.; Lund, O.; Villa, L.; Aarestrup, F.M.; Hasman, H. In SilicoDetection and Typing of Plasmids using PlasmidFinder and Plasmid Multilocus Sequence Typing. Antimicrob. Agents Chemother. 2014, 58, 3895-3903. [CrossRef] [PubMed]

120. Joensen, K.G.; Tetzschner, A.M.M.; Iguchi, A.; Aarestrup, F.M.; Scheutz, F. Rapid and Easy In Silico Serotyping of Escherichia coli Isolates by Use of Whole-Genome Sequencing Data. J. Clin. Microbiol. 2015, 53, 2410-2426. [CrossRef]

121. Zankari, E.; Allesøe, R.; Joensen, K.G.; Cavaco, L.M.; Lund, O.; Aarestrup, F.M. PointFinder: A novel web tool for WGS-based detection of antimicrobial resistance associated with chromosomal point mutations in bacterial pathogens. J. Antimicrob. Chemother. 2017, 72, 2764-2768. [CrossRef]

122. Clermont, O.; Bonacorsi, S.; Bingen, E. Rapid and Simple Determination of theEscherichia coli Phylogenetic Group. Appl. Environ. Microbiol. 2000, 66, 4555-4558. [CrossRef] [PubMed]

123. Darling, A.E.; Jospin, G.; Lowe, E.; Iv, F.A.M.; Bik, H.M.; Eisen, J.A. PhyloSift: Phylogenetic analysis of genomes and metagenomes. Peer] 2014, 2, e243. [CrossRef] [PubMed]

124. Price, M.N.; Dehal, P.S.; Arkin, A.P. FastTree 2-Approximately Maximum-Likelihood Trees for Large Alignments. PLoS ONE 2010, 5, e9490. [CrossRef]

Publisher's Note: MDPI stays neutral with regard to jurisdictional claims in published maps and institutional affiliations.

(C) 2020 by the authors. Licensee MDPI, Basel, Switzerland. This article is an open access article distributed under the terms and conditions of the Creative Commons Attribution (CC BY) license (http://creativecommons.org/licenses/by/4.0/). 